\title{
Az igei jelentés metaforizációjának mintázatai
}

\author{
Nyelvtan- és korpuszvezérelt esettanulmányok
}

\author{
Simon Gábor \\ ELTE Mai Magyar Nyelvi Tanszék
}

\begin{abstract}
Összefoglaló
A tanulmány újszerüen közelíti meg a metaforikus jelentést. Egyfelöl a Magyar Nemzeti Szövegtár2 korpuszában előforduló kollokációs struktúrák kvantitatív elemzésével tárja fel, milyen jellemző kollokációs megoldásai vannak a megtámadja, megrohanja, megrohamozza igealakok metaforizálódásának. Másfelől a profilmeghatározásra és a sematikus jelentés átrendeződésére építő magyarázattal kínál eszközt a metaforikus szerkezetek szürésére és kvalitatív elemzésére. A korpuszvezérelt és a nyelvtanvezérelt módszertan összehangolása mentén a tanulmány rámutat arra, hogy több különböző konstrukció stabilizálódik tipikus metaforikus jelentések kifejezésére, e konstrukciók azonban változatosságot is mutatnak. A metaforikus jelentés részleteinek leírásán túl új utakat keres a metaforakutatás módszertani és generalizációs lehetőségeiben, és előkészíti a metaforizálódás tendenciáinak nyelvi rendszerbe illesztett bemutatását.
\end{abstract}

Kulcsszavak: metafora; korpusz; profilmeghatározás; sémaátrendeződés; kollokáció; konstrukció

\section{Problémafelvetés - a metaforikus jelentés vizsgálatának lehetőségei}

Ez a tanulmány azzal a céllal készült, hogy a kognitív nyelvészeti metaforakutatás régi kérdéseit újszerü megközelítéssel vesse fel. Ma már egyértelműen látszik, hogy az ezredfordulót követően olyan szemléletmód bontakozott ki a nyelv kognitív szemléletű kutatásában, amelyet egyfelől a konceptualizációs-idealizációs és a használatalapú megközelítés integrációjának igénye, másfelől a belső sokféleség, a plurális metodológia biztosította diverzitás (és így a dogmatizálódás veszélyének elkerülése) jellemez (Strugielska 2014: 103-104). Ez a szemléletváltás egyúttal a deduktív módon bevezetett, nem pedig induktív módon levezetett fogalmi konstrukciók kapcsán erőteljes empirikus megalapozást kezdeményez, hiszen felismerhetővé vált, hogy a korai holista kognitív nyelvészet úttörő eredményei (a konceptualizációs megközelítés elméletei) voltaképpen heurisztikus modellek, fenntarthatóságuk és további innovációjuk immár nem nélkülözheti a nyelvhasználat adatainak szisztematikus feltárása felől érkező visszacsatolást.

A metafora jelensége esetében a szemléletváltás fokozottan érvényesült. A legvilágosabban talán Deignan fogalmazta meg a kognitív nyelvészeti metaforakutatás központi dilemmáját: „Úgy tűnik tehát, hogy míg egyrészt a kognitív hagyomány 
kutatói hajlamosak a nyelv jelentőségének alulértékelésére, azzal érvelve, hogy az másodlagos a gondolkodáshoz képest, mégis a nyelv mentén fejlesztik elméletüket és tudásukat" (Deignan 2008: 151). ${ }^{1}$ A fő kérdés tehát, hogy mi a viszonya az elmében lokalizált fogalmi metaforáknak és a nyelvben felfedezhető metaforikus kifejezéseknek. A klasszikus válasz jól ismert: a metafora nem a nyelv, hanem a konceptualizáció (fogalmi megértés, feldolgozás) jelensége, a metaforikus kifejezés pedig felszíni megvalósulás (Lakoff 2006: 185-186). Az ellenpontot Gerard Steen képviseli: a metafora mentális reprezentációja szerinte nem a nyelvtudomány, hanem a pszichológia kutatási területe, a nyelvészetnek a metaforikus kifejezések elemzését kell célul kitúznie (Steen 2007: 108). Ez utóbbi radikális álláspont ugyan kevéssé egyeztethető össze a korábban szorgalmazott elméleti és módszertani sokféleséggel, mégis e tanulmány Steen javaslatát követi annyiban, hogy nem tárgyalja a metaforikus jelentés fogalmi reprezentációját: az itt bemutatott vizsgálat eredményei nem járulnak hozzá egyetlen elméleti modell érvényességéhez vagy kritikájához sem.

A következőkben a metafora rendre a nyelv jelenségeként jelenik meg (összhangban a kutatás funkcionális nyelvelméleti kiindulópontjával, I. LadányiTolcsvai Nagy 2008), mégpedig kétféle aspektusból: egyfelöl összetett jelentésszerkezetként, amely az összetevők jelentéseinek műveleti integrálásával, és ennek során egy sematikus jelentéstől való egyértelmű eltávolodással alakul ki; másfelől nyelvi elemek együttes előfordulásaként, a nyelvhasználatban gyakori, így viszonylagosan rögzült összetett szerkezetként. Azaz egyszerre tekintem a metaforát olyan konstrukciónak, amely egy központi elem (ezúttal az ige) sémaszerü jelentése köré szerveződik, mégpedig e jelentés megváltozásán keresztül, továbbá szóalakok kapcsolatának, amely a metaforikus jelentésszerkezet kialakulását és közösségen belüli begyakorlottságát mutatja. Hangsúlyozni kell, hogy a metafora ebben a tanulmányban nem lexikológiai jelenség, mert a meghatározások a metafora összetett szerkezetére irányítják a figyelmet. Ezért bár a vizsgált kifejezések igealakok, a kutatás nem az ige poliszémiáját tárja fel, legfeljebb e poliszémia egyik jellemzőjét mutatja be korpuszadatok alapján.

Arra a kérdésre keresem tehát a választ, „,hogyan határozhatjuk meg nyelvi jegyek azon listáit, amelyek bármely természetes nyelvi szövegben metaforikus jelentésre utalnak" (Babarczy-Simon 2012: 224). A korpuszbeli együttes előfordulások alapos elemzése arra enged következtetni, hogy e nyelvi jegyek nem valamiféle grammatikai kapcsolat testes (morfológiai) vagy ikonikus (például szórendi) jelölői, hanem a kollokálódás (a gyakori egymás mellé kerülésből új nyelvi egységek stabilizálódásának) folyamatával ragadhatók meg. Elörebocsátva, és némiképp leegyszerüsítve a tanulmány fő következtetését: ha egy szövegben metaforikus jelentéseket kívánunk felismerni, akkor kollokációkat kell keresnünk, azok ugyanis jelentős mértékben korrelálnak a metaforikus jelentésképzéssel, másfelől a kollokációk szerkezete olyan jelentésstruktúra, amelyben egy-egy jellemző összetevő kezdeményezi a szerkezet egészének metaforikusságát.

1 "It seems then that while on the one hand researchers in the cognitive tradition tend to downplay the importance of language, arguing that it is secondary to thought, they nonetheless depend on language to advance theory and knowledge." 
A metaforikus jelentések konstrukcióinak feltárásához a korpusznyelvészeti módszereken túl a holista kognitív nyelvészet (összefoglalóan I. Tolcsvai Nagy 2013), közelebbről pedig a kognitív nyelvtan (Cognitive Grammar, Langacker 1987; 2008) előfeltevéseit érvényesítettem, és a következő eszköztárat mozgósítottam. E nyelvleírási kiindulópontból tekintve a nyelvi szerkezetek egy fonológiai és egy szemantikai pólus szimbolikus viszonyaként modellálhatók, a nyelvtan pedig az elemi egységek összetettebb szerkezetekben történő integrálását (azaz a fonológiai és a szemantikai pólusok műveleti összekapcsolását, egymásba ágyazását) írja le. Ezért a szókészlet és a nyelvtan nem elkülönülő területek, a lexikon, a morfológia és a szintaxis kontinuumot alkot, és a grammatikai elemeknek is tulajdonítható jelentés, noha igen sematikus. A jelentés a tapasztalatok sematizálásával, absztrahálásával és kategorizálásával jön létre, ezért a holista kognitív nyelvleírás központi fogalma a séma, amely a több megismerési eseményben visszatérő, közös mozzanatokat szervezi meg általánosságban. Jelentéssémáink mindig szerkezetesek, hiszen maguk a fogalmi reprezentációk is, amelyek e sémákat megalapozzák (a világról való tudásunk felől), összetettek. Mindazonáltal a diskurzusban konkrét, aktuális jelentéseket konstruálunk (alakítunk ki és dolgozunk fel), amelyek a sémák megvalósulásaiként elemezhetők. Séma és megvalósulás különböző távolságokra lehet egymástól a megismerésben, azaz a konkrét jelentés megőrizheti a séma szerkezetét (pusztán specifikálva azt bizonyos pontokon, miként az olvas igető sematikus figuráit a fiú könyvet olvas szerkezet), de el is távolodhat különböző módokon a sematikus struktúrától (miként az olvas igető jelentése a felolvassa a verset, az átolvassa a leckét, vagy a megolvassa a pénzt szerkezetekben). A séma megvalósulásának módja fontos szempont lesz a metaforák azonosításában a későbbiekben. Amennyiben azonban egy konkrét kifejezés sematikus jelentését, dekontextualizált értelmét (elsődleges referensét) határozzuk meg, kognitív nyelvtani terminussal élve a kifejezés profilját mutatjuk be (igék esetén temporális viszony, azaz folyamat, főnevek esetén entitás, minősítő kifejezéseknél, morfológiai elemeknél vagy határozószóknál általában atemporális viszony). Séma és megvalósulás kapcsolata a kifejezés profiljának alakulásával is megragadható. Ily módon a nyelvtan összetett szerkezeteinek kialakítása az egyes összetevők profiljainak egymáshoz igazításával megy végbe, amely a metafora nyelvtanvezérelt megközelítésében kap majd fontos szerepet.

A kutatás összhangban van a kognitív nyelvészet devolúciós tendenciájával, amely az idealizált formulák helyett precíz fenomenológiai és módszertani deklarációkat fogalmaz meg (I. Strugielska 2014: 104). A tanulmányban a metaforikus jelentés korpuszbeli előfordulásait elemzem (három kiválasztott igealak, a megtámadja, a megrohanja és a megrohamozza² kollokációs mintázatának feltérképezésén keresztül), vagyis nem egy előzetesen elfogadott metaforamodell mentén jelölöm ki a vizsgálat kategóriáit: a kutatás korpuszvezérelt, nem csupán korpuszalapú. Célom, hogy a lehető legközelebb jussak a metaforikus jelentés tényleges

\footnotetext{
${ }^{2}$ Azért esett ezekre a kifejezésekre a választás, mert a kognitív nyelvészeti metaforakutatásban több esetben is (I. Deignan 2005; 2008; Semino 2006) a HARC, HÁBORÚ forrástartományok, valamint az azokhoz kapcsolódó megfelelések feltárásán keresztül szemléltetett módszertani lehetőségeket. Következésképpen célszerűnek tünt a nemzetközi szakirodalomban már vizsgált jelentéskörnél megmaradni az új módszerek tesztelése során is.
} 
megvalósulásaihoz, minimálisra csökkentve az elméleti előfeltevések determináló szerepét, s maximálisra növelve elmélet és empíria összhangját.

Ugyanakkor nem pusztán elemezni szeretném egyes kifejezések metaforizációját, hanem egyúttal javaslatot is szeretnék tenni arra, melyek lehetnek a metaforikus jelentés azonosításában használható nyelvi jegyek. A kollokálódást, azaz a nyelvi szerkezetek rendszeres együttes előfordulását tekintem olyan jellemző jelenségnek, amely a metaforikus jelentés felmutatásában és elemzésében egyaránt új eredményekhez vezethet. Annak eldöntése azonban, hogy egy korpuszbeli kollokáció metaforikus-e, az empirikus elemzés objektivitásába az elemzői intuíció szubjektivitását csempészheti vissza. Hogy csökkentsem az intuíció jelentőségét, a tanulmányban a metaforikus kifejezéseket nem csupán együttesen előforduló nyelvi mintázatként, hanem grammatikai mintázatként is vizsgálom, a kognitív nyelvtan és a mintázatnyelvtan eszköztárával, építve a korábbi nyelvtanvezérelt vizsgálat tanulságaira (I. Simon 2016).

A tanulmány először a korpuszvezérelt kutatás elméleti és módszertani jellemzőit tárgyalva előzetes hipotézist fogalmaz meg a metaforikus kifejezések vizsgálatához (2). Ezt követően a metafora grammatikai elemzésének lehetőségeit mutatja be, kialakítva a kutatás úgynevezett kombinált hipotézisét (3). Majd a vizsgált anyag és a vizsgálat módszereinek tárgyalását (4) követően a vizsgálat eredményeit részletezi (5). A tanulmányt a legfontosabb következtetések összefoglalása zárja (6).

\section{Metafora és korpusz}

A kognitív nyelvészetben már a kétezres években egyértelmű eredményeket hozott a metaforikus kifejezések annotált korpuszokban történő kutatása (Deignan 2005; 2008; Stefanowitsch 2006a). Az egyik fő eredmény, hogy a metaforikus leképezések, fogalmi struktúrák immár nem labormondatok elemzésével mutathatók be; a nyelvhasználat adatainak vizsgálata révén kutathatóvá vált, milyen forrás- és céltartományok müködnek közre ténylegesen a metaforikus gondolkodásban, hogyan strukturálja a forrástartomány a céltartományt, továbbá az elvontabb fogalmak feldolgozására milyen forrástartományok fordulnak elő a korpuszban. A másik fontos eredmény, hogy a figyelem ráirányult a metaforikus kifejezések szerkezetére: például a fogalmi metaforáknak leginkább megfelelő azonosító kifejezések (mint a sokat idézett Ez a sebész egy hentes mondat, I. Kövecses 2009) meglehetősen ritkán jelennek meg a vizsgált korpuszokban (Deignan 2008: 152). Viszont a kifejezések metaforikus használata grammatikai kötöttségeket mutat, azaz gyakori és elkülönülő nyelvi megformálás figyelhető meg egyazon kifejezés szó szerinti és a metaforikus használata között, ilyen az idiomatizálódás vagy a szófajváltás. (Az angol nyelvben például az állatnevek metaforizálódása mutatja ezt, mint a fat cat 'gazdag és tekintélyes celebritás, üzletember vagy politikus' (Deignan 2005: 155), valamint a squirrel away szófajváltása 'elrejtve felhalmoz' (Deignan 2006: 109) jelentésben.)

\subsection{Korpuszalapú vagy korpuszvezérelt?}

A korpusz elemzése azonban nem csupán új lehetőségeket teremt a metaforakutatásban, hanem újabb, elsősorban módszertani nehézségeket is. A legfőbb ezek 
közül annak eldöntése, hogy miként nyerjünk ki az adathalmazból metaforákat. Az egyik lehetőség a céltartománynak megfelelő kifejezések keresése (Stefanowitsch 2006b; I. még Majoros 2013), a másik a forrástartománynak megfelelő kifejezések konkordanciáinak kinyerése (Deignan 2008). Ugyanakkor felmerül az a módszertani döntés is, hogy csak azokat a mondatokat tekintsük metaforikusnak, amelyekben mindkét tartomány explikálódik nyelvileg (Babarczy-Simon 2012: 234; Lederer 2016: 530). Közös ezekben a kutatásokban, hogy a metafora konceptualizációs modelljéből, azaz a fogalmi metaforából kiindulva törekednek metaforikus jelentések korpuszbeli azonosítására. Vagyis azzal az előfeltevéssel élnek, hogy a fogalmi metafora adekvát modellje a metaforikus jelentésnek, a céljuk pedig, hogy e modell egyes összetevőit előtérbe helyezve megfigyelhetővé tegyék a metaforikus nyelvhasználatot motiváló leképezéseket. Ezek a kutatások tehát elméletvezérelt vállalkozások: egy elméleti modellből levezetett struktúrák szisztematikus feltárását végzik el, ezért korpuszalapú vizsgálatoknak tekinthetők (Tognini-Bonelli 2001; Deignan 2008: 155; Biber 2010: 162).

A korpuszalapú kutatások célkitűzése „olyan rendszerszerü használati mintázatok felfedezése, amelyek vezérlik az általános nyelvelmélet révén felismert nyelvi jellemzőket”, 3 legjelentősebb hozadékuk pedig „meglepő” mintázatok kimutatása, amelyek nem következnek a kutató intuíciójából, előfeltevéseiből (Biber 2010: 163). A korpuszbeli mintázatok, azaz a konkrét nyelvi szerkezetek azonban nem mindig „jólformáltak” az elméleti előfeltevések felől tekintve. Miként Babarczy és Simon eredményei is mutatják, sok problémás esettel találkozik a kutató: hiányzik a céltartományra utaló kifejezés, vagy nem ugyanabban a mondatban fordul elő, továbbá lexikalizálódott, illetve összetett szóként jelenik meg a metaforikus jelentés (Babarczy-Simon 2012: 237). A korpuszalapú kutatás tehát még előzetesen reflektált keresési módszer és átgondolt döntések esetén sem nélkülözheti az adatok egy részének kézi elemzését. Ez egyfelől továbbra is teret enged az elemző professzionális intuíciójának (Majoros 2013: 141; Lederer 2016: 542), másfelöl a metaforák korpuszalapú keresése nem automatizálható teljes mértékben. Márpedig a korpuszkutatások távlati célja a gépi metaforakeresés, illetve a metaforaazonosítás automatizálásának lehetővé tétele.

Éppen ezért irányult a figyelem az utóbbi években a kollokációkra: kifejezések együttes előfordulására, amely a statisztikai valószínűségnél nagyobb gyakoriságot mutat (Brunner-Steyer 2009: 55); más értelmezésben olyan együttes előfordulásokra, amelyek nem idiomatikusak, de nem is triviálisak, vagyis nem megjósolhatók (Reményi 2010: 69), ám a teljesen szabad variálódás felől tekintve rendszerszerüen jelennek meg a nyelvhasználatban. Már Deignan (2005) felhívja a figyelmet a metaforák kollokációs mintázatainak stabilitására, amelyet a magyar nyelvre irányuló kutatás is megerősít (Babarczy-Simon 2012: 238). Újabban Lederer (2016) dolgozott ki kevert módszert a metaforák korpusznyelvészeti vizsgálatára, amelyben egy előzetes kvalitatív elemzéssel tárja fel a forrástartományhoz kapcsolódó kifejezéseket, ám nem a forrástartomány szemantikai ontológiáját építi ki (azaz nem azt vizsgálja, hogy a forrástartomány hányféle nyelvi kifejezéssel asszociálódik), hanem a feltárt forrástartományi kifejezések kollokációit elemzi.

${ }^{3}$ „The goal is (...) to discover the systematic patterns of use that govern the linguistic features recognized by standard linguistic theory." 
A forrástartomány tehát voltaképpen címkeként, „kollokációs mágnesként” funkcionál (Lederer 2016: 536) azoknak a kifejezéseknek az összegyűjtésére, amelyek a forrástartományi kifejezéssel (source domain trigger) gyakran asszociálódnak a nyelvhasználatban.

Jól látható, hogy a korpusz kínálta lehetőségek kihasználását akkor tudjuk fokozni, ha a kutatás középpontjába magukat a korpuszbeli előfordulásokat, adatokat helyezzük, nem pedig az elméleti modellből levezetett kategóriákat. Más megfogalmazásban: a metaforikus jelentés nyelvi-szerkezeti megvalósulásának vizsgálata nem korpuszalapú, hanem korpuszvezérelt módszerekkel válhat igazán eredményessé. A korpuszvezérelt kutatás lényegi jellemzője, hogy a vizsgált jelenség nincs előzetesen definiálva, minimális nyelvelméleti-teoretikus előfeltevésekkel él az elemző, így teret enged a korpuszban megfigyelhető jelenségeknek, vagyis a kutatás tárgya az adatok megfigyeléséből bontakozik ki (Biber 2010). Ily módon egy korpuszvezérelt kutatás nem már ismert jelenségek szisztematikus feltárását végzi, hanem teljesen új konstrukciók azonosítását eredményezi, az (1) alatt összefoglalt alapelvek mentén (Brunner-Steyer 2009 alapján).

A korpuszvezérelt kutatás módszertani elvei

A: A vizsgálat kiindulópontja a lehető legközelebb álljon a valós nyelvhasználathoz: a korpusz minden adata vizsgálandó, ezek az adatok maguk képezzék a vizsgált jelenséget.

B: A vizsgálat hipotézisének megalkotása a korpusz adataira alapuljon: egymáshoz kapcsolódó lépésekben kell megalkotni és folytonosan finomítani az elemzés hipotézisét.

C: A hipotézist empirikusan kell ellenőrizni: feltevéseink plauzibilitása a korpusz adatainak újbóli elemzésével mérhető le, azaz hipotézisünket a vizsgálat minden pontján a korpuszadatokkal kell szembesítenünk.

D: A generalizálásnak több szinten kell megtörténnie: a vizsgálat eredményeiből különböző szinteken szükséges következtetéseket levonni, általánosításokat megfogalmazni, hogy a kutatás ne túlgeneralizált használati szabályokhoz, hanem a nyelvhasználat valódi összetettségének bemutatásához vezessen.

Ebben a tanulmányban a fenti elvek megvalósításával teszek kísérletet a metaforikus igei jelentés kollokációs mintázatainak bemutatására. A radikális korpuszvezérelt kutatás már az adatok kinyerésénél sem fogad el semmilyen általánosítást: nem lemmatizál, mert minden szóalak esetében önálló grammatikai-használati profilt feltételez; továbbá semmilyen előzetes elméleti definíciót nem alkalmaz az adatgyüjtés során (Biber 2010: 168-169). Saját módszerem csak részben folytatja ezt a hagyományt: a megtámadja, megrohanja, megrohamozza szóalakokra keresve magam is kerültem a lemmatizálást, hogy a lehető legpontosabban állíthassam össze e kifejezések kollokációs profilját, megfigyelve, vajon van-e kapcsolat a metaforikus jelentés és a kollokálódás között. Ugyanakkor alkalmaztam előzetes definiálást a metaforikus kifejezés meghatározásánál, miként ez majd a vizsgálat nyelvtanvezérelt aspektusának részletezésénél bemutatom. 


\subsection{A korpuszvezérelt kutatás hipotézisei}

A korpuszvezérelt nyelvleírás nagyszabású vállalkozása az angol nyelvre vonatkozóan az úgynevezett mintázatnyelvtan (Pattern Grammar, Hunston-Francis 2000), amely a Bank of English adataira, előfordulásaira és mintázataira alapozott angol nyelvtan: az angol nyelv szerkezeteit, grammatikai struktúráit a korpuszban megfigyelhető együttes előfordulásokból generalizálva mutatja be. E nyelvtan egyik fontos tétele, hogy egy kifejezés egyes jelentései elkülönülő szerkezeti/kollokációs mintázatokhoz kapcsolódnak a nyelvhasználatban (Hunston-Francis 2000: 83). Amennyiben ezt a megfigyelést összevetjük a metafora korpuszalapú kutatásának eredményével, miszerint a metaforikus jelentés tipikus kollokációs mintázatokba rendeződik a nyelvhasználatban, grammatikai megformálása tehát konvencionálódott (Deignan 2005: 145; Deignan 2008: 188), többféle hipotézis fogalmazható meg a metaforikus jelentés korpuszvezérelt vizsgálatához.

Ezek a hipotézisek elrendezhetők aszerint, hogy mennyire stabil szerkezeti mintázatokat tartunk megfigyelhetőnek a korpuszban (Hunston-Francis 2000: 86 alapján).

A metafora korpuszvezérelt kutatásának gyenge hipotézise: a partikuláris mintázatban gyakran előforduló kifejezések nem teljesen véletlenszerűen szerveződnek a jelentés tekintetében.

Azaz találunk majd olyan egyéni, konkrét kollokációkat, amelyek összefüggésbe hozhatók a kollokálódó kifejezések metaforizálódásának tendenciáival. Ugyanakkor az egyes esetek rögzülésén túl nem tételezhetünk általánosabb összefüggést metafora és együttes előfordulások között. Ez voltaképpen az idiomatizálódás hipotézise: a metaforikus jelentés néhány nagyon gyakori, erősen konvencionálissá váló esetben szerkezetileg rögzül.

(3) A metafora korpuszvezérelt kutatásának erős hipotézise: egy kifejezés azért rendeződik partikuláris mintázatba, mert egy konkrét jelentést fejez ki ez a mintázat.

Azaz a metaforikus jelentések nem egyszerüen összefüggést mutatnak bizonyos mintázatba rendeződési tendenciákkal: stabil és egyértelmű mintázatok különíthetők el aszerint, hogy a kifejezés jelentése metaforikus vagy szó szerinti, és az egyes metaforikus jelentések is egyértelműen önálló grammatikai mintázatokkal szimbolizálódnak. Az erős hipotézis szerint a metaforizálódás új mintázatokat motivál és stabilizál, lényege pedig a kizárólagosság: egy adott metaforikus jelentés egyértelműen egyféle kollokációs szerkezetben jelenik meg, másban nem, ezért ha azonosítjuk a szerkezeteket, a metaforikus jelentés automatikus azonosítása is elvégezhető.

Az imént felvázolt módszertan értelmében a fenti alternatívákat a korpusz adataival kell szembesítenünk - amennyiben megfigyelhetők lesznek stabil kollokációs mintázatok, fel kell tárni e sablonok és a metaforikus jelentések közötti lehetséges összefüggéseket. Ha azonban a megtámadja igealak legvalószínübb kollokációjelöltjeinek listáját áttekintjük a Magyar Nemzeti Szövegtár2 (v2.0.4, OraveczVáradi-Sass 2014) adatai alapján, ${ }^{4}$ az adatokból egyáltalán nem maguktól

${ }^{4}$ A kollokálódás méréséhez, pontosabban fogalmazva a kollokációjelöltek sorba rendezéséhez a logDice értéket használtam, ennek okait részletesen a 4. szakaszban fejtem ki. 
értetődően rajzolódnak ki a minket érdeklő mintázatok. Olyan kifejezések együttes előfordulása regisztrálható a korpuszban a szóban forgó igealakkal, mint a csokipultot, az Alkotmánybíróságon, a gépüket, az Afganisztánt, a hóembert, vagy az immunrendszere. Mint látjuk, az igével szimbolizált folyamat végrehajtója, tárgya és határozóval jelölt körülménye is megjelenik, tehát grammatikailag variábilis a kollokálódás. Ha ezt a változatosságot összefüggésbe lehetne hozni a metaforikussággal, az egyértelműen a (3) felvetését támogatná. Ám ehhez pontosan el kellene tudnunk különíteni a metaforikus és a nem metaforikus jelentéseket. A radikális korpuszvezérelt módszertan mentén ez csupán elemzői intuícióval tehető meg, hiszen egy ilyen kutatásban nem támaszkodik az elemző a metafora elméleti modelljére. Miközben tehát a korpusz adataiból látjuk kibontakozni a vizsgált jelenséget és annak kategóriáit, magának a jelenségnek a körülhatárolásánál nem tudjuk kizárni a professzionális intuíciót. Ez a dilemma több módon is feloldható. Egy használatalapú leírásban megvizsgálhatjuk például, hogy a nyelvhasználók mely kollokációkat ítélik metaforikusnak, s melyeket nem. E vizsgálat reprezentatívvá tétele azonban további nehézségeket támaszt, nem beszélve arról, hogy a metaforikusságra nehéz anélkül rákérdezni, hogy az adatközlőket ne tájékoztatnánk elöre, mit tekintünk metaforikus jelentésnek, ez pedig torzítja az eredményt.

Ezért a saját vizsgálatomban a fenti dilemmát azzal oldottam fel, hogy lazítottam a korpuszvezérelt módszertan radikalizmusán, és elméleti előfeltevéseket, előzetes elemzési módszert alakítottam ki a metaforikus kollokációk szürésére. A vizsgált igealakok metaforikus használatának meghatározásához azonban nem tértem vissza a metafora egyik vagy másik fogalmi reprezentációs modelljéhez - az elemző módszer középpontjába a metafora nyelvtanát helyeztem, hogy a grammatikai elemzéssel egyúttal a kollokációk magyarázatát is előkészítsem. Ebben a tanulmányban a metaforikus jelentés tehát egyfelöl olyan nyelvi mintázat, amely a korpuszban egy kiválasztott szóalak bizonyos együttes előfordulásainak nyalábjaként adódik - a vizsgálat korpuszvezérelt; továbbá olyan jelentésszerkezet, amely specifikus grammatikai struktúrában bontakozik ki műveletileg - a vizsgálat nyelvtanvezérelt.

\section{A metafora nyelvtanvezérelt elemzése}

Egy korábbi kutatás (Simon 2016) során megkülönböztettem a metafora nyelvtanalapú és nyelvtanvezérelt elemzési módszereit: míg az előbbiek - hasonlóan a korpuszalapú kutatásokhoz - elfogadják a metafora fogalmi modelljét kiindulópontként, a nyelvtani elemzést pedig a fogalmi metafora nyelvi reprezentálódásának leírásaként valósítják meg, addig az utóbbiak egyáltalán nem foglalkoznak azzal Steen (2007) mintájára -, milyen mentális reprezentációs struktúrák rendelhetők a metaforikus jelentéshez, céljuk kizárólag annak megfigyelése és szisztematikus leírása, hogy az egyes kifejezések metaforikus alkalmazásba vétele milyen grammatikai jellegzetességekkel korrelál. E megkülönböztetés értelmében a kognitív nyelvtan keretében kidolgozott, e nyelvleírás eszköztárát alkalmazó elemző módszerek egyaránt nyelvtanalapúak. A legjelentősebb javaslatot Croft (1993) tette, a fogalmi autonómia/függőség aspektusára alapozva. A kognitív nyelvtan szerint a konstruálás folyamatában kompozitumszerkezeteket hoz létre és ért meg a konceptualizáló; ezek a nyelv grammatikai struktúrái, amelyek azonban egyben 
szemantikai struktúrák is, kialakulásuk és konvencionálódásuk fogalmilag motivált, azaz a nyelvhasználó világról való tudását szimbolizálja velük mások számára hozzáférhető módon. A kompozitumszerkezet komponensszerkezetek szemantikai integrálódásaként elemezhető: az egyik komponens fogalmilag specifikálja (kognitív nyelvtani terminussal kidolgozza) a másik komponens sematikus alszerkezetét. Egy ige és egy fónév grammatikai kapcsolata például azon alapul, hogy az igével jelölt folyamat résztvevői csak sematikusan állnak rendelkezésre a nyelvhasználó számára (VALAKI olvas VALAMIT), ${ }^{5}$ a fönév jelentése azonban pontosítja az egyik vagy a másik résztvevőt ( a fiú olvas vagy olvas egy könyvet és így tovább), ezen a pontosító-kidolgozó szemantikai műveleten alapul grammatikai viszonyuk. Az a komponensszerkezet, amely kidolgozza egy másik komponens sematikus alszerkezetét, fogalmilag autonóm, míg az a komponens, amelynek az alszerkezetét egy másik komponens kidolgozza, fogalmilag függő (Langacker 1987: 300; Langacker 2008: 199). ${ }^{6}$ Croft grammatikai elemzése értelmében a metaforikus jelentést a fogalmilag autonóm szerkezet kezdeményezi a függő komponensben. Noha Croft nem kívánja megfeleltetni a fogalmilag autonóm tartományt a forrástartománynak (s ez az esetek többségében nem is lenne lehetséges, ugyanis megfigyelhető, hogy a metaforikus kifejezéseknél gyakran a fogalmilag függő komponens, például az ige vagy a melléknév tekinthető forrástartományi kifejezésnek, I. Lederer 2016 adatait a source domain trigger kifejezésekről), a metaforikus jelentést mindazonáltal két tartomány közötti leképezésnek tekinti, azaz nem egyenrangú összetevők egyirányú viszonyának.

A crofti elemzés implicit elméletvezéreltsége más módszerekben explicitté válik. Leginkább Sullivan (2009) épít Croft örökségére: megközelítésében a függő komponens feleltethető meg a forrástartománynak, az autonóm pedig a céltartomány kifejezéseként vesz részt a konstruálásban. Azaz Sullivan egyértelműen a fogalmi metafora modelljéből kiindulva elemzi a metaforikus kifejezések nyelvi megformálását. Túl azon, hogy elemzéseinek közel 40\%-ában (például a birtokos konstrukciókban vagy az összetételekben) nem egyértelmü, vajon a fogalmilag függő komponens valóban kezdeményezője-e a metaforikus jelentés kialakulásának (hiszen a fogalmilag függő komponens nem feltétlenül a leginkább feltűnő tagja a szerkezetnek, az összetett szók esetében pedig sokszor kölcsönös kidolgozást figyelhetünk meg), Sullivan javaslata módszertanilag sem ígéretes: a fogalmi függőség közvetlenül nem szimbolizálódik explicit módon a nyelvekben, így nem annotálható és

\footnotetext{
${ }^{5} \mathrm{~A}$ kognitív nyelvészet konvenciói szerint a fogalmi struktúrákat KISKAPITÁLISSAL jelölöm a tanulmányban.

${ }^{6}$ Megjegyzendő, hogy e két kategória nem abszolutizálható, hiszen a FIÚ esetében is lényeges, hogy milyen folyamat résztvevőjeként válik a diskurzusvilág részévé, azaz az ige jelentése is közremüködik a fiú főnév jelentésének konstruálásában. Mégis karakteresen elválasztható egymástól a komponensek azon csoportja, amelyek eleve sematikus alszerkezettel bírnak (ilyenek többek között a derivációs és inflexiós morfémák, az igék, a melléknevek), így önállóan nem válhatnak teljes értékű közlésegységgé, csak egy másik kifejezéssel együtt. Bár a magyar véges igealak magmondatként önálóan is megnyilatkozássá válhat (pl. Elment. Megérkeztünk!), amennyiben a folyamat résztvevője a diskurzusvilágban kidolgozható, ismert, ezért nyelvileg nem szükséges explikálni (erről részletesen I. Imrényi 2017). Ez azonban nem érvényteleníti azt, hogy a kompozitumszerkezetben az igealak továbbra is függő komponens.
} 
nem kereshető a korpuszban. Maga Sullivan is manuálisan szűrte ki a saját korpuszából a metaforikus adatokat, és azokat kvalitatív elemzésnek vetette alá, elemzési javaslata ezért nehezen operacionalizálható.

A metaforakutatás nyelvtanvezérelt elemzését leginkább Huumo (2017) valósította meg: a temporális metaforikus kifejezések kognitív nyelvtani leírását végezte el az angol nyelvre vonatkozóan. Az idő metaforizálódásának lehetőségeit vizsgálva a grammatikai jellemzők mentén tesz javaslatot metaforikus (igékkel és prepozíciós szerkezetekkel megvalósított) és nem metaforikus (az igeidőn és az ige aspektusán alapuló) jelentés elkülönítésére. Egyúttal elkülönülő grammatikai mintázatként mutatja be az igékkel és a prepozíciós szerkezetekkel történő metaforizálást: az idő mozgásként történő metaforikus szimbolizálásában a prepozíciós struktúrák (Christmas is ahead) kevéssé intenzívek, szemben az igével kifejezett mozgással (The financial problem has been approaching us for years). Ennek hátterében az áll, hogy az ige a tagmondat profilmeghatározó komponense, vagyis az ige fogalmi profilja lesz a tagmondat egészének fogalmi alapstruktúrája; a mozgás prepozícióval történő kifejezése során a metaforikus jelentés gyengébb és kevésbé áll előtérben (Huumo 2017: 39-40). Huumo részletes elemzései meggyőznek arról, hogy a grammatikai vizsgálat nem korlátozódik a fogalmi metaforák alátámasztására: a metaforikus jelentés azon jellemzőire irányítja a figyelmet, amelyek a fogalmi reprezentáció felöli megközelítésben nem válnának felismerhetővé. Továbbá az egyes metaforikus jelentéseket a grammatikai szerkezetek mentén különíti el, ezzel azonosithatóvá és kereshetővé tesz metaforikus konstrukciókat, összefüggést találva a grammatikai megformálás és a metaforizálódás között.

Huumo azonban mélységi, kvalitatív elemzéseket végez az idő nyelvi megformálását vizsgálva, így bár eredményei hasznosíthatók a metaforikus nyelvhasználat tendenciáinak bemutatásában, közvetlenül nem építhető rájuk korpuszvezérelt vizsgálat. Ha ugyanis mozgást kifejező igékre keresünk rá a korpuszunkban, a kapott adatokat a tagmondat komplex jelentésviszonyai mentén további elemzéseknek kell alávetnünk, hogy elkülöníthessük a metaforikus szerkezeteket, illetve azok alcsoportjait. A korpusz adatainak szüréséhez olyan nyelvtanvezérelt metaforaelemzésre van szükség, amely egyszerübb eszköztárral, a vizsgált kifejezés közvetlen grammatikai környezetére összpontosítva nyújt megbízható alapot az elkülönítésre.

Építhető ilyen elemzés a Huumo által felvetett profilmeghatározás jelenségére. Tekintsük a metaforikus kifejezést kompozitumszerkezetnek, amelyben a profilált, előtérbe helyezett és a konstruálás során részleteiben kidolgozott jelentést alapvetően az egyik összetevő, a profilmeghatározó adja. Egy névszói tő + esetrag kompozitumban (szobában) a profilmeghatározó az esetrag: az ugyanis (hely)viszonyt fejez ki, miként a szerkezet egésze, a főnévi tő pedig meghatározza a lokalizálást. Egy melléknév + főnév kompozitumban (sárga könyv) a főnév a profilmeghatározó, hiszen a kompozitum egésze is entitást, fizikai tárgyat tesz hozzáférhetővé, miként a főnévi komponens, a melléknév pedig specifikálja ezt az entitást a megismerés valamely dimenziójában. Egy főnév + ige kompozitumban a folyamatot profiláló ige lesz a profilmeghatározó, mert a fiú olvas szerkezet ugyanúgy egy folyamatot szimbolizál, ám immár kidolgozott résztvevővel, vagyis a folyamat egyben eseményként is kidolgozható. A profilmeghatározó tehát az a komponens, amelynek a profilja megegyezik a kompozitum profiljával (Langacker 2008: 193), vagyis örökíti profilált jelentését a kompozitum egésze számára. Ebben a megközelítésben akkor 
tekinthetjük metaforikusnak a szerkezetet, ha a porfilmeghatározó komponens profilja megváltozik a jelentés konstruálása során, azaz ha át kell alakítania a konceptualizálónak a sematikus profilt ahhoz, hogy a konkrét kifejezés jelentését kialakíthassa. A metaforizáció a komponensek integrálása során bontakozik ki: a szerkezet egyik komponense csak akkor integrálható a szerkezet egészébe, ha a profilmeghatározó komponens profilját módosítja a konceptualizáló, egyúttal a szerkezet egészének sémáját átrendezi, rekonfigurálja a dinamikus jelentésképzés folyamatában (Simon 2016).

Tekintsük példaként a megtámad igető jelentéseinek példáit az Értelmezó Kéziszótár ${ }^{7}$ anyaga alapján.

(4) a. Megtámadták a sötétben.

b. Megtámadták az erődöt.

c. A dohányzás megtámadta a tüdejét.

d. Megtámadták a cikkéért.

e. Megtámadták a végrendeletet.

A (4a) esetében ugyan nincsen nyelvileg jelölve sem a támadást végrehajtó, sem az azt elszenvedő szereplő, ám a kifejezés jelentése különösebb erőfeszítések nélkül feldolgozható, hiszen nem kell az ige profilját módosítanunk: a 'támadást intéz, indít vki, vmi ellen' sematikus jelentés aktiválható a mondat jelentésének kialakítása során. A (4b)-t a szótár ugyancsak a fenti alapjelentés példájaként mutatja be. Ezúttal azonban - és ez ellenérv a szótárban megfigyelhető jelentésadással szemben - már megfigyelhető némi változás az ige profilált jelentésében, hiszen nem egy személy elleni, tettleges és közvetlen fizikai agresszióról, hanem csoportosan elkövetett, komplex, általában fegyveres támadásról van ez esetben szó. Ugyanakkor ez a változás nem az igei profil módosítása, átalakítása, pusztán jelentésbeli kiterjesztése: a támadásban többen vesznek részt, specifikus eszközöket (például nehézfegyverzetet vagy más ostromlásra alkalmas eszközt) használnak, a folyamat célpontja pedig egy (katonai) objektum, illetve az azt védő emberek, tehát az alapjelentés metonimikus kiterjesztéséről beszélhetünk ebben az esetben.

Hasonlítsuk össze a (4a-b)-t a (4c)-vel: az utóbbi esetben a nyelvhasználó már nem hagyatkozhat az ige aktivált sematikus profiljára, hiszen itt a támadást nem ember követi el, nem beszélhetünk tettleges agresszióról, a folyamat pedig nem gyors és intenzív. Az ÉKSz. a 'káros, romboló hatást kezd kifejteni valami(be)n' jelentés példájaként közli a (4c) mondatot, vagyis önálló jelentést különít el. Ennél a példánál tehát már megfigyelhetünk profilváltást, mind az igével jelölt folyamat minősége, jellege, mind pedig sematikus résztvevői másként dolgozhatók ki, mint a korábbi esetekben.

\footnotetext{
${ }^{7}$ Az adatok forrása: www.szotar.net, az elérés időpontja 2017. 04. 27. Ezen a ponton fel kell hívni a figyelmet arra, hogy a szótári jelentésadások bemutatásának a tanulmányban csupán szemléltető funkciója van. Nem kívánom a vizsgált kifejezések profilját vagy egyéb jelentéseit azonosítani a szótár által felkínált jelentésekkel, miként nem tartom a szótári leírásokat a vizsgált jelentések kimerítő és teljes étékű megragadásának. A szótárra alapozott metaforaazonosítás nemzetközi módszere (MIPVU, I. Steen et al. 2010) hangsúlyozottan korpuszalapú szótárakkal dolgozik, ráadásul nem is eggyel, hogy a kapott eredmények árnyaltak és megfelelőek legyenek. Mivel jelenleg a magyar nyelvre vonatkozóan nincs korpuszalapú teljes szótárunk, az itt bemutatott példák csupán a megértést könnyítik, nem az elemzés bemeneti adatai.
} 
Ugyancsak megváltozik a profil a (4d-e) esetekben: az előbbi példa kapcsán (prototipikusan) nem beszélhetünk fizikai erőszakról, a támadás eseménye sokkal inkább verbális jellegű (vö. 'vádoló, sértő v. számon kérő hangon nekitámad vkinek, vminek'); az utóbbi esetben pedig igen messze kerülünk a tettlegességtől, hiszen a jogi keretek ennek kizárására jöttek létre, a támadás célpontja pedig immár metonimikusan sem emberi létező, hanem egy jogi döntés (vö. 'jogi határozat, döntés érvénytelenítéséért eljárást indít").

A (4a-e) példák egyrészt azt a régi belátást erősítik meg, hogy a szó szerinti és a metaforikus jelentés között kontinuum tételezhető. Lényeges azonban, hogy a profil változásának vizsgálata nem leegyszerüsíti ezt a kontinuumot, hanem feltérképezhetővé teszi azáltal, hogy a sematikus profil kiterjesztését és különböző irányú, erősségű módosulásait egyaránt felmutatja. Másrészt a profilmeghatározó komponens jelentésének megváltozása mint elemzési szempont azért produktív javaslat, mert az elemzőnek nem arról kell döntenie, metaforikusnak érzi-e a kifejezés adott használatát, hanem azt kell vizsgálnia, megfigyelhető-e átrendeződés, változás a profilmeghatározó komponens jelentésében a kompozitumszerkezethez viszonyítva, így a metaforikus találatok szürésénél nagymértékben csökkenthető a professzionális intuíció (még ha az elemzés jelenlegi kidolgozottságában teljesen ki nem is zárható). Végül komoly előnye a profilmeghatározásra épülő elemzésnek, hogy jól operacionalizálható: első lépésben a vizsgált konstrukciót komponensek mentén kell elemezni, majd ezt követi a profilmeghatározó komponens meghatározása, végül a profil megváltozásának vizsgálatával eldönthető, metaforikusnak minősül-e a kifejezés aktuális használata. Mindhárom lépés ellenőrizhető, visszakövethető analízist feltételez. A komponensek a szerkezet összetevői, meghatározásuk és elkülönítésük a teljes idiomatizálódás esetét leszámítva elvégezhető. A profilmeghatározó kijelölése összevetésen alapul: a kompozitumszerkezet egészének jelentését hasonlítjuk össze a komponensek sematikus jelentésével, $s$ ahol egyezést vagy átfedést találunk, azt tekinthetjük profilmeghatározónak. Ez utóbbi fogalmi profiljának megváltozása pedig ismét összevetéssel állapítható meg, annak felmérésével, mennyiben más a jelentése a kompozitumszerkezetnek a komponensszerkezet jelentéséhez képest. Hangsúlyozni kell azonban, hogy a profilváltás tényének megállapításán túl annak mértéke a módszer jelenlegi kidolgozottságában nem határozható meg egzakt módon, az elemzés ugyanis kvalitatív jellegü, a skalaritás kvantitatív feltérképezésére más eszközök bevonása is szükséges lesz a jövőben. Ugyanakkor nem is cél jelenleg a metafora fokozati jellegének pontos mérése, a korpuszvezérelt kutatáshoz elegendő, ha arról hozunk döntést, metaforikus-e egy szerkezet vagy nem.

Ezen a ponton célszerü összekapcsolni a korpuszvezérelt és a nyelvtanvezérelt módszert. A metaforikus kifejezéseket korábban a korpusz kollokációs mintázataiként értelmeztem. Amennyiben igealakok metaforizálódását vizsgáljuk, a kifejezés egyfelől kollokációs mágnes, azaz többé-kevésbé stabil együttes előfordulási mintázatokban szerepel. Másfelöl ugyanakkor profilmeghatározó is egy kompozitumban, vagyis a kifejezés metaforikusságának megállapításában központi tényező. Ebből ismét két alternatív hipotézis következik.

(5) Gyenge kombinált hipotézis: A stabil kollokációs minták és a profil megváltozásának elemzésével feltárt metaforizációs tendenciák között lesz valamiféle összefüggés. 
Azaz a metaforizáció, az igealak mint komponens köré szerveződő kompozitumszerkezet sémája nem véletlenszerüen valósul majd meg a korpuszban, hanem egyes esetekben visszatérő konkrét kollokációkba rendeződik a nyelvhasználatban. Ez a kollokálódás csak egyedi esetekre korlátozódik (idiómák).

(6) Erős kombinált hipotézis: az elkülönülő metaforikus kollokációs mintázatok egyúttal specifikus grammatikai konstrukciók is, vagyis az, hogy milyen kollokációjelöltek fordulnak elő a vizsgált igealak metaforikus használata során, egyértelmű grammatikai relevanciával bír, elkülönülő konstrukciós sablonokba rendeződik.

Azaz a metaforikus jelentés típusai nyelvtani szerkezetként, pontosabban szerkezeti sémákként azonosíthatók: bizonyos jelentések bizonyos grammatikai konstrukciókkal asszociálódnak a korpusz adatai alapján, másokkal pedig nem. Ez esetben a kizárólagosság tehát grammatikai is: egy nyelvtani szerkezet (pl. ige + bizonyos esetraggal ellátott főnév) lefoglalódik egyféle metaforikus jelentés kifejezésére.

A kombinált hipotézis mindkét változata örökli a korpuszvezérelt szemléletmódot és módszertant, azt azonban a nyelvtani elemzés alapján finomítva és specifikálva fogalmazza meg. A tanulmány elején megfogalmazott módszertani elvek teljesülnek: a vizsgált jelenség a korpuszból bontakozik ki (kollokációs mintázatok), a kutatás hipotézise folyamatosan formálódik, az adatok feldolgozásának, értékelésének folyamatában. A hipotézisalkotás folyamata ugyanakkor magát az elemzési módszert, továbbá az elemzés eszköztárát is finomítja és gazdagítja: nem csupán árnyalja a metafora értelmezését, hanem egyre hatékonyabb eszközöket nyújt a körültekintő elemzéshez. A következő lépés a kombinált hipotézis változatainak vizsgálata a korpusz adatai alapján.

\section{Anyag és módszer}

A továbbiakban három igealak, a megtámadja, a megrohanja és a megrohamozza kollokációs mintázatainak elemzését mutatom be azzal a céllal, hogy a kombinált hipotézis (5-6) érvényességét meghatározzam. A kollokációs mintázatokat az MNSz2 (közel 1,5 milliárd szövegszavas) nagykorpuszából nyertem. A megtámadja igealak összesen 2152 esetben fordult elő a korpuszban, a megrohanja jóval ritkábban (89 előfordulás), míg a megrohamozza a legritkább (42 előfordulás). Az utóbbi két kifejezés alacsony gyakorisága a hapaxok torzító hatásának veszélyével jár, ám a kutatás módszertanának alkalmazhatósága, valamint a megtámadja esetében kapott eredmények relevanciájának felmérése érdekében kiterjesztettem a kutatást e két ritka szóalakra is.

A kollokálódás mértékének meghatározásához több mutató is alkalmazható az MNSz2 korpuszában. Mind a magyar (Reményi 2010: 81-84), mind a nemzetközi gyakorlatban (Church-Hanks 1990; Cheng 2012: 94-95; Lederer 2016: 536) a köIcsönös információ együtthatója (MI-érték, Mutual Information) vált bevetté a kollokálódás mérésére ( $\mathrm{MI}>3$ érték esetén szignifikáns a kollokálódás, Church-Hanks 1990: 24 alapján). Ez az érték az együttes előfordulás relatív gyakoriságához (azaz a kollokációnak a korpusz összes szövegszavához mért gyakoriságához, Reményi 2010: 81) képest megbízhatóbb, mert a funkciószavak mellett nagyobb arányban 
vezet el a lexikális kollokáltakhoz. Az MI-együttható ugyanis azt mutatja meg, hogy a szerkezet tagjainak önálló előfordulási aránya hogyan viszonyul az együttes előfordulási arányukhoz. Tehát ezzel a mutatóval nem csupán azt tárhatjuk fel, hogy a két kifejezés milyen gyakran fordul elő a korpuszban, hanem azt is, hogy mennyire asszociálódnak egymással. Ugyanakkor az önmagukban ritkán előforduló kifejezések (hapaxok) prominensebbek lesznek a kollokációjelöltek listájában (Cheng 2012: 94; Reményi 2010: 84), hiszen ha két ritka kifejezés egymás mellé kerül, akkor együttes előfordulásuk igen magas értéket mutat önálló gyakoriságukhoz viszonyítva. Ez a torzítás azzal ellensúlyozható, hogy az eleve alacsony gyakoriságú kifejezéseket nem vizsgáljuk kollokációs csomópontokként. Éppen ezért nem számít megfelelő vizsgálati anyagnak a megrohanja és a megrohamozza szóalak, alacsony gyakorisága miatt.

Mégsem hagytam ki ezeket a kifejezéseket, több okból. Egyrészt a hapaxok magas prominenciája, torzító hatása mellett is vizsgálható a kifejezések kollokációs profilja (hiszen nem pusztán hapaxokként fordulnak elő, még ha ritkák is az MNSz2 korpuszában), amely a metaforikusság korpuszvezérelt kutatásának jelenlegi fázisában hasznos eredményekkel járhat. Másrészt egy másik kollokációs mutató, a logDice választásával némiképp ellensúlyozható a kifejezések ritkaságának torzító hatása. A Dice-együttható nem növeli az együttes előfordulások mértékét indokolatlanul nagyra (nem az összes szóelőfordulással szorozza meg, hanem a dupláját veszi csupán), és nem az önálló előfordulások szorzatával osztja el az együttes elöfordulás gyakoriságát, hanem az összegével (azaz minimális önálló előfordulásánál nagyobb érték szerepel a nevezőben), ezért minél ritkábban fordulnak elő a tagok önmagukban, annál megbízhatóbb asszociációs értékhez vezet (Rychlý 2008: 7-8). A logDice pedig a Dice együttható kettes alapú logaritmusával korrigált változat, amelyből egy relatív asszociációs érték következik: maximum értéke 14 (ekkor a kifejezések minden előfordulása egyben együttes előfordulás, vagyis hapaxról vagy idiomatizálódott kifejezésről van szó), minimuma pedig 0 (ekkor kevesebb mint 1 előfordulás van 16.000 önálló előfordulásokként); negatív érték esetén nem beszélhetünk kollokálódásról; két érték összehasonlításában az eggyel növelt logDice érték kétszer gyakoribb kollokációt mutat, a héttel növelt érték százszor gyakoribb együttes előfordulást (Rychlý 2008: 9). A logDice érték tehát kellően megalapozott kollokációs mutatónak tekinthető, ráadásul nem függ a korpusz méretétől, így korpuszok közötti összehasonlításra is alkalmas. Ezért a vizsgálatban ezen együttható alapján rangsoroltam és elemeztem a stabil kollokációs mintázatokat.

A kollokációs profil feltérképezéséhez, azaz a stabil kollokációjelöltek kiválogatásához és mintázatba rendezéséhez nem lett volna elegendő az MNSz2 nyújtotta konkordanciaelemzés. Az ugyanis listába rendezi a kollokáltakat a kiválasztott együttható mentén, amelyből egyrészt ki kellett válogatni a metaforikus kollokációkat (a kutatás jelen pontján ez még nem automatizálható, a cél a nyelvtanvezérelt elemzéssel az intuíció minimalizálása volt), másrészt maguk a kollokációs mintázatok sem rajzolódtak ki a lista lineáris reprezentációjában. Ez persze feloldható alapos átvizsgálással és újrarendezéssel, ám a kollokációk feltérképezéséhez felhasználtam a GraphColl alkalmazást is (Brezina-McEnery-Wattam 2015), amely a konkordancia betáplálásával előállítja a kulcskifejezés (azaz a kollokációs csomópont) kollokáltjainak grafikus, hálózati reprezentációját. A program nem csak megkönnyíti a mintázatok azonosítását, hanem lehetővé teszi a csomópont 
változtatását, azaz egy kollokált kifejezés saját kollokációs profiljának feltérképezését is (Baker 2016). Noha a kutatás jelenlegi fázisában nem vizsgáltam kollokációs hálózatok létét a konkordanciákban, a későbbiekben a GraphColl további előnyei is kamatoztathatók lesznek. Az itt bemutatott vizsgálatban az eszköz használtalának legfőbb célja az volt, hogy az elemzői intuíciót (azaz a kollokációjelöltekből generalizált csoportokat) ellenőrizhetővé tegye a grafikus reprezentáció és egy újabb, a programba beépített automatikus korpuszelemzés bevonásával. ${ }^{8}$

A kollokációs ablakot négy szóban határoztam meg a kulcskifejezéstől jobbra és balra is, összhangban a magyar nyelvre vonatkozó korábbi javaslatokkal (Reményi 2010: 80). Próbálkoztam kisebb ablakkal is (kétszónyi méretűvel), ám a szűkítés nem eredményezett megbízhatóbb eredményeket. Sőt: nagyobb mérési ablak esetén több téves találat is előfordult (például az erős kollokációjelölt egy másik tagmondatban tünt fel), ám ez a „statisztikai zaj” nem minősült számottevőnek (vagyis a találatok manuális ellenőrzése nem eredményezett nagy mennyiségü hibás találatot), ugyanakkor a megnövelt keresési ablak általánosabb asszociációkra adott módot, és relevánsabb adatokhoz vezetett (I. Lederer 2016: 537).

A korpuszvezérelt kutatás egyik alapelve a többszintű általánosítás: egy nyelvi szerkezet különböző variációkban ismétlődhet a korpuszban, ezért körültekintő döntést kell hozni abban, milyen mintázato(ka)t vonatkoztat el a kutató az elemzés során. Egy kollokáció a maga konkrétságában a vizsgálat eredménye lehet (I. Brunner-Steyer 2009): ekkor az derül ki, hogy a kulcskifejezés (grammatikailag összetett alakként) milyen más kifejezésekkel (korpuszbeli példányokkal) fordul elő szignifikánsan (felszíni mintázat). Ám egy kollokációs adatsorból elvonatkoztatható egy séma tipikus megvalósulásainak, azaz lexikális realizációinak mintázata, a konstrukciók sematikus hálózata, sőt, e konstrukciók egészen absztrakt jelentésmintázatai is, például igék esetén tematikus szerepekkel, argumentumok jelölésével és így tovább.

A metaforikus jelentés korpuszvezérelt kutatásában három általánosítási szintet alkalmaztam. Elsőként a vizsgált kifejezések kollokációs profilját térképeztem fel: azt a felszíni mintázatot, amely megmutatja, mely más konkrét kifejezésekkel mint példányokkal kollokálódik jellemzően a korpuszban az igealak. Ezután a profilt fogalmi csoportosításnak vetettem alá, hogy felderítsem, az egyes kollokáltak milyen aspektusát helyezik előtérbe az ige jelentésének (a cselekvőt, az elszenvedőt, a körülményeket), és milyen jelentésszerkezeti sémát valósítanak meg. Vagyis a fogalmi csoportosítás egyúttal a kollokálódó példányok típusokba rendezésének kísérlete is - az egyedi együttes előfordulásokból tendenciák megállapítása, a sematizálás kezdeti lépése, de még a kollokáltak jelentésére vonatkoztatva. Végül a mintázatnyelvtan reprezentációs eljárását alkalmazva (I. Hunston-Francis 2000) leképezési táblázatokat formáltam az adatokból, amelyek tartalmazzák a tipikus kollokációjelölteken túl azok kapcsolódási erősségét és a szerkezetek tagjainak grammatikai jellemzőit (szófajiság, illetve az igei eseményszerkezeten belüli funkció) is. Ezzel a metaforizálódó jelentés konstrukciós mintázatait, azaz a kollokációk hátterében meghúzódó szerkezeti sémákat tártam fel, amelyben már a kognitív

${ }^{8} \mathrm{~A}$ program első lépésben kicseréli az ékezetes karaktereket ékezet nélküliekre, így némiképp átalakítja az eredeti konkordanciát, de ez az általam elvégzett vizsgálatban nem torzította az eredményeket. 
nyelvtan terminusai mentén kategorizáltam a kollokációs struktúrák komponenseit, egyúttal összevethetővé tettem azok korpuszbeli stabilitását. A leképezési táblázatok kialakítása mutatja fel a legelvontabb sablonokat, ugyanakkor nélkülözhetetlen, mert a metaforikus jelentést nem a szó, hanem egy összetett szerkezet szintjén teszi azonosíthatóvá. Azaz a vizsgálat eredményeképpen a metafora nem szószemantikai jelenségként, hanem konstrukcióként adódik.

\section{A vizsgálat eredményei}

A továbbiakban sorra veszem az adatokból kirajzolódó mintázatokat. Az eredményeket kifejezésenként közlöm, a mintázatok bemutatásánál a generalizáció szintjei mentén haladok, a felszíni mintázattól a fogalmi csoportosításon át a leképezési táblázatokig. Az eredmények ismertetése során a korpuszban megfigyelhető tendenciák bemutatása a célom, nem pedig az összes adat kimerítő elemzése. Alaposan kidolgozott összképet szeretnék nyújtani a vizsgált igealakok metaforikus használatának kollokálódási és grammatikai jellemzőiről, ezért az egyes jelenségnyalábok részletezése mellett általánosabb megfigyelések is helyet kapnak az eredmények között, a többszintű generalizáció módszertana alapján.

\subsection{A megtámadja igealak jelentésének metaforizálódása az MNSz2-ben}

A kifejezés 2152 előfordulással szerepel a vizsgált korpuszban. A kollokációjelöltek nyelvtanvezérelt elemzésével, azaz a profilváltás azonosításával összesen 89 kollokáltat vizsgáltam (kiszűrve azokat az együttes előfordulásokat, amelyek nem a kulcskifejezéssel együtt alkotnak grammatikai szerkezetet). Az asszociációs együttható (logDice) maximális értéke 9,568 (demonstrálva megtámadja - hapax jellegü adat $^{9}$ ), minimális értéke 2,459 (megtámadja az eredményt). A logDice együttható esetében nincs konvenció arról, milyen értéktől számít az együttes előfordulás stabil kollokációnak, ugyanakkor a közel 2,5-es érték kellően alacsony ahhoz, hogy a kollokációjelöltek tág körét áttekinthessem, ezért húztam meg az elemzett adatok határát ennél az értéknél.

\subsubsection{A megtámadja igealak kollokációs profilja az MNSz-ben}

A kollokációs profil feltérképezésében a korpusz kínálta adatsorokat és a GraphColl elemzéseit egyaránt felhasználtam. A legstabilabb kollokációjellöltek listáját az alábbi táblázat foglalja össze.

\footnotetext{
${ }^{9}$ A fenti szerkezetnek 60 előfordulását találja meg a keresőmotor az MNSz2 korpuszában, ugyanakkor mindegyik esetben azonos a szövegkörnyezet. A dokumentumokat megvizsgálva felfigyelhetünk arra, hogy mind a 10 szövegfájl a Facebook közösségi oldalról származó bejegyzést tartalmaz, vagyis könnyen lehet, hogy egyazon Facebook-poszt kerül több alkalommal is a korpuszba, köszönhetően annak, hogy a bejegyzést újraközölték a közösségi oldalon. Noha a szerkezet egyik tagja sem hapax önmagában, és nagy számú együttes előfordulásuk regisztrálható a korpuszban, ezek mindegyike egyetlen adat ismétlődése. Ezért tekintem hapax-kollokáltnak a demonstrálva szóalakot a kulcskifejezés mellett.
} 


\begin{tabular}{|c|c|c|c|c|c|}
\hline & & Fred & T-score & $\mathrm{Ml}$ & logDice \\
\hline $\mathrm{p} / \mathrm{r}$ & demonstrálva & 60 & 7.746 & 16.499 & 9.586 \\
\hline $\mathrm{p} / \mathrm{r}$ & Iránt & 38 & 6.164 & 13.715 & 8.310 \\
\hline $\mathrm{p} / \mathrm{r}$ & csokipultot & 18 & 4.243 & 19.105 & 8.085 \\
\hline $\mathrm{p} / \mathrm{r}$ & Alkotmánybíróságon & 23 & 4.796 & 14.321 & 8.044 \\
\hline $\mathrm{p} / \mathrm{r}$ & gépüket & 17 & 4.123 & 15.125 & 7.829 \\
\hline $\mathrm{p} / \mathrm{r}$ & alkotmánybíróságon & 13 & 3.605 & 15.087 & 7.480 \\
\hline $\mathrm{p} / \mathrm{r}$ & megfutamítsa & 11 & 3.317 & 19.016 & 7.379 \\
\hline $\mathrm{p} / \mathrm{r}$ & Afganisztánt & 14 & 3.741 & 13.343 & 7.259 \\
\hline $\mathrm{p} / \mathrm{r}$ & Irakot & 17 & 4.122 & 12.652 & 7.193 \\
\hline $\mathrm{p} / \mathrm{r}$ & közreműködőt & 10 & 3.162 & 15.419 & 7.158 \\
\hline $\mathrm{p} / \mathrm{r}$ & megerőszakolja & 9 & 3.000 & 14.575 & 6.951 \\
\hline $\mathrm{p} / \mathrm{r}$ & Lengyelországot & 16 & 3.999 & 12.215 & 6.943 \\
\hline $\mathrm{p} / \mathrm{r}$ & intézkedésben & 10 & 3.162 & 13.140 & 6.847 \\
\hline $\mathrm{p} / \mathrm{r}$ & hóembert & 9 & 3.000 & 13.636 & 6.828 \\
\hline $\mathrm{p} / \mathrm{r}$ & elúzi & 10 & 3.162 & 12.955 & 6.800 \\
\hline $\mathrm{p} / \mathrm{r}$ & Szovjetuniót & 10 & 3.162 & 12.636 & 6.707 \\
\hline $\mathrm{p} / \mathrm{r}$ & immunrendszere & 10 & 3.162 & 12.505 & 6.665 \\
\hline $\mathrm{p} / \mathrm{r}$ & vagyona & 26 & 5.097 & 11.115 & 6.487 \\
\hline $\mathrm{p} / \mathrm{r}$ & idegrendszert & 8 & 2.828 & 12.546 & 6.454 \\
\hline $\mathrm{p} / \mathrm{r}$ & kapitulál & 6 & 2.449 & 15.100 & 6.443 \\
\hline $\mathrm{p} / \mathrm{r}$ & igénybevételével & 10 & 3.161 & 11.679 & 6.334 \\
\hline $\mathrm{p} / \mathrm{r}$ & államhatalom & 10 & 3.161 & 11.659 & 6.324 \\
\hline $\mathrm{p} / \mathrm{r}$ & megszállja & 6 & 2.449 & 13.015 & 6.237 \\
\hline $\mathrm{p} / \mathrm{r}$ & tisztújítási & 5 & 2.236 & 15.055 & 6.190 \\
\hline $\mathrm{p} / \mathrm{r}$ & becsületbiróság & 5 & 2.236 & 14.851 & 6.181 \\
\hline $\mathrm{p} / \mathrm{r}$ & szövetségeseit & 6 & 2.449 & 12.478 & 6.128 \\
\hline $\mathrm{p} / \mathrm{r}$ & vírus & 39 & 6.241 & 10.540 & 6.105 \\
\hline
\end{tabular}

1. táblázat

A megtámadja legstabilabb kollokációjelöltjei az MNSz2 adatai alapján

Már ebből az adatsorból is egyértelmű, hogy a kollokációjelöltek nem rendeződnek egyértelműen elkülönülő mintázatokba a grammatikai viselkedésük mentén (alanyi, tárgyi és körülményhatározói szintaktikai szerepű kifejezések egyaránt megjelennek, noha döntően a nem alanyesetben álló szóalakok dominálnak). A kollokációs profil feltárásának további nehézsége, hogy a közeli kollokálódás nem szükségképpen jelent szoros grammatikai-szemantikai integrációt: a becsületbíróság kifejezés például kellően stabil kollokációs partner, de nem a támadási aktus végrehajtójaként jelenik meg a korpusz adataiban, hanem a megtámadott döntés meghozójaként, birtokos szerkezetben (például Tökés megtámadja a becsületbíróság döntését). A lista tehát nem transzparens a kollokációk szerkezetét tekintve, a kézi elemzés emiatt nem nélkülözhető a korpuszvezérelt kutatások kezdeti fázisában. Az is látszik az adatokból, hogy a kollokációjelöltek a jelentés szempontjából sem mutatnak egyértelmüen elkülönülő mintázatokat: a (4a-e) alatt felsorolt jelentések csaknem mindegyike megjelenik a leginkább stabil kollokációk körében (egyedül a (4d)-re nem találunk közvetlen példát). Tendenciák azonban megfigyelhetők. Gyakori a (4b) 'fegyveres támadás' jelentést kezdeményező kifejezés (például Iránt, Afganisztánt, Szovjetuniót). A (4e) 'jogi érvényesség megkérdőjelezése' jelentés inkább körülményhatározók mentén (például alkotmánybíróságon) kollokálódik. A (4c) 'fiziológiai károsodás' jelentés adatai nagyobb arányban alanyesetben áló kifejezések (immunrendszere, vírus), kisebb arányban tárgyként tűnnek fel (idegrendszert). 
Az utóbbi jelentés kiterjesztésével eloaáló 'virtuális károkozás' jelentést azonban egyértelműen tárgyesetben álló kifejezés képviseli, előkelően magas kollokációs mutatóval (gépüket).

A legelső adatsorok is tanúsítanak tehát már valamilyen mintázatban rendeződést, ám annak bemutatásához további elemzések szükségesek. A GraphColl alkalmazás előnye e kutatás perspektívájából elsősorban abban van, hogy olyan reprezentációs felületet kínál, amelyben a kollokációjelöltek rétegekbe rendeződése figyelhető meg. ${ }^{10}$

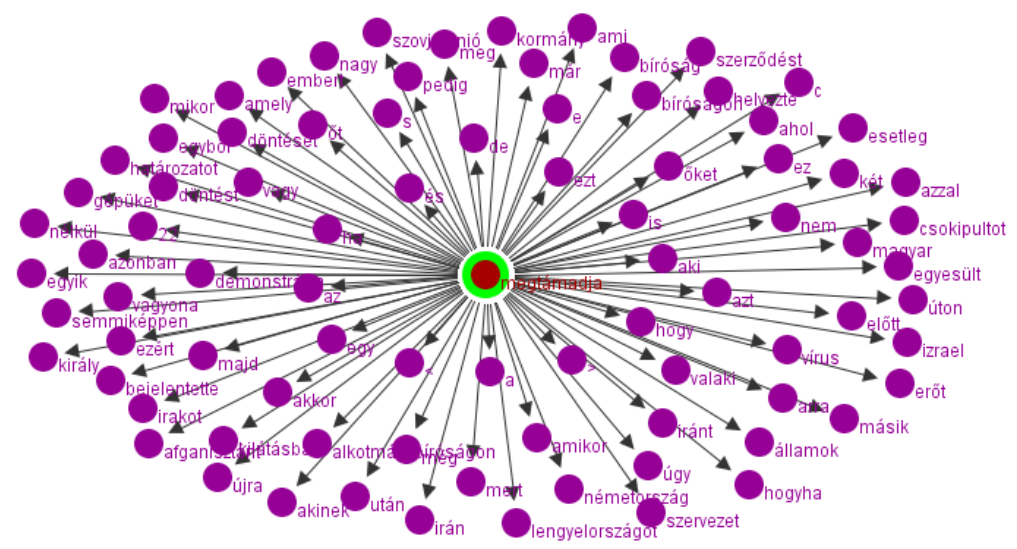

1. ábra

A megtámadja szóalak kollokációjelöltjei 7,5 logDice küszöbérték mellett

Az ábrán centrális helyzetben látható a kulcskifejezés, a vizsgált szóalak. A kollokációjelöltek köré rendeződnek, a megjelenítésben a nyilak hossza a kollokálódás erősségét szimbolizálja. (A nyilak elrendeződésének nincs jelentősége az értelmezésben, a nyilak iránya pedig a kollokálódás szimmetrikusságát vagy aszimmetrikusságát mutatja (I. Brezina-McEnery-Wattam 2015: 162). Ez utóbbi szempontra a jelen vizsgálat nem tért ki.) A kollokációs profilban elmosódó határok mutatkoznak, nem különülnek el élesen almintázatok sem a jelentés, sem a grammatikai viselkedés mentén. Egyelőre tehát a (6) erős kombinált hipotézise nem igazolható, hiszen

${ }^{10} \mathrm{~A}$ szemléltető felület nagy mennyiségű adat rendezett bemutatására alkalmas átlátható módon. Más vizualizációs eszközök (elsősorban diagramok) nehezebben feldolgozható reprezentációs módot kínálnak. Az alkalmazás további lehetőséget kínál a kollokáltak kulcskifejezéssé tételére (a tanulmányban közölt ábrák tehát rögzített pillanatfelvételeket adnak az adatokról), de az így elemezhető gráfszerű alakzatokra egy új vizsgálatban lehet majd kitérni. Mindezen túl a GraphColl a konkordanciát az MNSz2 adataiból nyeri, ám nem egyszerüen átveszi annak kalkulált listáját, hanem saját algoritmusai mentén újraszámolja a kollokáltak körét, lehetővé téve egyfelől az adatok feldolgozásának szoros kontrollját, enyhítve másfelől az MNSz2-ben tapasztalható torzításokon (I. például a demonstrálva kollokált pozícióját az ábrán, amely korántsem olyan kiugró jelentőségű, mint azt az MNSz2 kalkulációja mutatja az 1. táblázatban). 
nem figyelhető meg egyértelmű összefüggés a metaforikus kollokációk jelentése és grammatikai szerveződése között. Ugyanakkor a középpontból kiindulva megfigyelhetők rétegszerüen, skaláris tartományokként elrendeződő adatok: a legbelső tartományba névelők, kötőszók és névmások kerülnek, a második rétegbe már metaforikus kollokáltakat is tartalmaz, a külső tartományban pedig gyakoriak a metonimikus jelentéskiterjesztést kezdeményező adatok. Kérdés, hogy csak a gyenge kombinált hipotézis tartható fenn (azaz van valamilyen összefüggés a kollokációs minták jelentése és grammatikai jellemzői között), vagy esetleg egy köztes tézis fogalmazható meg, illetve hogy egyáltalán milyen összefüggés állhat fenn a kollokációk jelentése és nyelvtani megformálása között.

Az ugyanis határozottan felismerhető, hogy míg a metaforikus jelentések nem különülnek el mereven kollokációs almintázatokba, a körvonalazódó jelentéseken belül van grammatikai preferencia. A (4b) 'fegyveres támadás' jelentés esetében például - amely nem metaforikus, ugyanakkor elkülöníthető jelentés - az igealakkal stabilabban kollokálódik a támadás célpontja grammatikai tárgyként, mint a támadó fél, azaz a kollokációjelöltek között több alkalommal fordul elő a célpont (grammatikai tárgyként), mint a támadó (grammatikai alanyként). A (4e) 'jogi érvényesség megkérdőjelezése' jelentésben a stabilabb (gyakrabban előforduló és magasabb kollokációs értékkel bíró) kollokációjelöltek a támadási esemény körülményét teszik hozzáférhetővé, és csak másodlagos a megtámadott dokumentumra referáló kollokált. És bár a GraphColl fenti adatai más asszociációs értéknél mutatnak be pillanatfelvételt a kollokálódásról, mint az MNSz2-ből nyert táblázat (minél alacsonyabb ugyanis a küszöbérték, annál kevésbé átlátható a vizuális reprezentáció), az is feltűnő, hogy a (4c) 'fiziológiai károsodás jelentésben csupán nominativusi esetű kollokációjelöltek fordulnak elő (vírus, szervezet), míg a kiterjesztett 'virtuális károkozás' jelentésben csupán tárgyesetben álló kifejezés (gépüket).

A kollokációs profil vizsgálata alapján tehát a következőket fogalmazhatjuk meg: (i) a megtámadja igealak metaforikus jelentései nem véletlenszerüen társulnak más kifejezésekkel, a grammatikai szerkezet formálódása az egyes jelentésekkel összefüggést mutat; (ii) ez az összefüggés azonban nem egyértelmű korreláció, azaz nem feleltethető meg egy az egyben egy metaforikus jelentés egy preferált felszíni kollokációs mintázatnak. Az összefüggések feltárásához a fogalmi csoportosítás lépését szükséges elvégezni.

\subsubsection{A megtámadja igealak kollokációs profiljának fogalmi csoportjai}

A fogalmi csoportosítás lényege, hogy a kollokációjelöltek adatai mellett vizsgálhatóvá tesszük azt a konceptuális kategóriát, amelyet a megtámadás fogalmi keretében az adott kollokációs partner hozzáférhetővé tesz, és azt a grammatikai mintázatot is, amelyet a felszíni kollokáció megvalósít (az elemzés hátteréről I. Hunston-Francis 2000: 83-95). Ez magasabb szintjét kínálja a generalizációnak: arról ad információt, hogy az igealak kollokációs környezete milyen tipikus fogalmi és nyelvtani kategóriákat valósít meg. A kérdés tehát továbbra is az, hogy melyek a tipikusnak tekinthető mintázatok a kollokálódás folyamatában, ám ezúttal a konkrét kifejezések felöl már a mélyebb sémák felé haladva vizsgálódom. 


\begin{tabular}{|c|c|c|c|}
\hline Kollokációjelölt & logDice & Mintázat & Fogalmi csoport \\
\hline demonstrálva & 9.586 & $\mathrm{adv}+\mathrm{v}$ & A megtámadás módja \\
\hline Iránt & 8.310 & $\mathrm{v}+\mathrm{nO}$ & Akit/amit megtámadnak \\
\hline csokipultot & 8.085 & $\mathrm{v}+\mathrm{nO}$ & Akit/amit megtámadnak \\
\hline Alkotmánybíróságon & 8.044 & $v+n$ Set & A megtámadás kerete/közege \\
\hline gépüket & 7.829 & $\mathrm{v}+\mathrm{nO}$ & Akit/amit megtámadnak \\
\hline alkotmánybíróságon & 7.480 & $v+n$ Set & A megtámadás kerete/közege \\
\hline Afganisztánt & 7.259 & $\mathrm{v}+\mathrm{nO}$ & Akit/amit megtámadnak \\
\hline Irakot & 7.193 & $\mathrm{v}+\mathrm{nO}$ & Akit/amit megtámadnak \\
\hline közremüködőt & 7.158 & $\mathrm{v}+\mathrm{nO}$ & Akit/amit megtámadnak \\
\hline Lengyelországot & 6.943 & $\mathrm{v}+\mathrm{nO}$ & Akit/amit megtámadnak \\
\hline hóembert & 6.828 & $\mathrm{v}+\mathrm{nO}$ & Akit/amit megtámadnak \\
\hline Szovjetuniót & 6.707 & $\mathrm{v}+\mathrm{nO}$ & Akit/amit megtámadnak \\
\hline immunrendszere & 6.665 & $\mathrm{nS}+\mathrm{v}$ & Aki/ami megtámad \\
\hline idegrendszert & 6.454 & $\mathrm{v}+\mathrm{nO}$ & Akit/amit megtámadnak \\
\hline szövetségeseit & 6.128 & $\mathrm{v}+\mathrm{nO}$ & Akit/amit megtámadnak \\
\hline vírus & 6.105 & $\mathrm{nS}+\mathrm{v}$ & Aki/ami megtámad \\
\hline cápa & 6.042 & $\mathrm{nS}+\mathrm{v}$ & Aki/ami megtámad \\
\hline Alkotmánybíróságnál & 5.995 & $v+n S e t$ & A megtámadás kerete/közege \\
\hline Szíriát & 5.976 & $\mathrm{v}+\mathrm{nO}$ & Akit/amit megtámadnak \\
\hline sejteket & 5.975 & $\mathrm{v}+\mathrm{nO}$ & Akit/amit megtámadnak \\
\hline fémeket & 5.956 & $\mathrm{v}+\mathrm{nO}$ & Akit/amit megtámadnak \\
\hline Finnországot ${ }^{*}$ & 5.933 & $\mathrm{v}+\mathrm{nO}$ & Akit/amit megtámadnak \\
\hline bíróságon* & 5.910 & $v+n S e t$ & A megtámadás kerete/közege \\
\hline anyóst & 5.833 & $\mathrm{v}+\mathrm{nO}$ & Akit/amit megtámadnak \\
\hline fogzománcot & 5.831 & $\mathrm{v}+\mathrm{nO}$ & Akit/amit megtámadnak \\
\hline Egyiptomot & 5.780 & $\mathrm{v}+\mathrm{nO}$ & gtámadnak \\
\hline Kuvaitot & 5.777 & $\mathrm{v}+\mathrm{nO}$ & Akit/amit megtámadnak \\
\hline idegrendszerét & 5.744 & $\mathrm{v}+\mathrm{nO}$ & Akit/amit megtámadnak \\
\hline immunrendszer & 5.733 & $n S+v$ & Aki/ami megtámad \\
\hline démon* & 5.728 & $\mathrm{nS}+\mathrm{v}$ & Aki/ami megtámad \\
\hline kór & 5.726 & $n S+v$ & Aki/ami me \\
\hline gépünket & 5.686 & $\mathrm{v}+\mathrm{nO}$ & gtámadnak \\
\hline Phobos & 5.671 & $\mathrm{nS}+\mathrm{v}$ & Aki/ami megtámad \\
\hline sejtjeit & 5.649 & $\mathrm{v}+\mathrm{nO}$ & Akit/amit megtámadnak \\
\hline szomszédait & 5.590 & $\mathrm{v}+\mathrm{nO}$ & ámadnak \\
\hline végeredményt & 5.583 & $\mathrm{v}+\mathrm{nO}$ & Akit/amit megtámadnak \\
\hline tüdőt & 5.546 & $\mathrm{v}+\mathrm{nO}$ & Akit/amit megtámadnak \\
\hline cellulitiszt & 5.507 & $\mathrm{v}+\mathrm{nO}$ & Akit/amit megtámadnak \\
\hline olvadéka & 5.503 & $n S+v$ & Aki/ami megtámad \\
\hline Meridiánt & 5.499 & $\mathrm{v}+\mathrm{nO}$ & Akit/amit megtámadnak \\
\hline gyümölcsmoly & 5.494 & $\mathrm{nS}+\mathrm{v}$ & Aki/ami megtámad \\
\hline szürkepenész & 5.489 & $\mathrm{nS}+\mathrm{v}$ & Aki/ami megtámad \\
\hline munilia & 5.478 & $\mathrm{nS}+\mathrm{v}$ & Aki/ami megtámad \\
\hline Japánt & 5.449 & $\mathrm{v}+\mathrm{nO}$ & Akit/amit megtámadnak \\
\hline alkotmánybíróságnál & 5.445 & $v+n S e t$ & A megtámadás kerete/közege \\
\hline Bizáncot & 5.415 & $\mathrm{v}+\mathrm{nO}$ & Akit/amit megtámadnak \\
\hline bacilus & 5.413 & $\mathrm{nS}+\mathrm{v}$ & Aki/ami megtámad \\
\hline perzsákat & 5.401 & $\mathrm{v}+\mathrm{nO}$ & Akit/amit megtámadnak \\
\hline kórháztörvényt & 5.385 & $\mathrm{v}+\mathrm{nO}$ & Akit/amit megtámadnak \\
\hline Wizair & 5.384 & $\mathrm{nS}+\mathrm{v}$ & Aki/ami megtámad \\
\hline
\end{tabular}

2. táblázat

A megtámadja igealak legstabilabb 50 kollokáltjának fogalmi csoportosítása. A csillaggal jelölt esetekben a nagyobb kollokációs ablak torzította az eredményt. A szürkével kiemelt adatok metaforikusak. 
A fenti táblázat a vizsgált 89 kollokációjelöltből 50 adaton szemlélteti a fogalmi csoportosítás módszerét. A leggyakoribb fogalmi csoport a támadást elszenvedő résztvevőé, amelyet a v+nO (igealak és nominális objektum) szerkezet tesz hozzáférhetővé. Ezzel a sémával valósul meg mindenekelőtt a (4b) kiterjesztett jelentés ('fegyveres támadás'): feltűnő, hogy a fegyveres agresszió végrehajtója csak egyetlen adattal jelenik meg (Phobos), és az is erősen metonimikus használatú (Miután Meridián elesik, Phobos megtámadja Kandakar erődjét). Stabilan kollokálódik ebben a sémában a 'virtuális károkozás' metaforikus jelentés, továbbá a vizsgált adatok között ebben a mintázatban 7 olyan kollokált van, amely a (4c) 'fiziológiai károsodás' metaforikus jelentést kezdeményezi. A 'kémiai károsodás' kiterjesztett jelentés csak két adattal jelenik meg a vizsgált mintában, ám a támadást elszenvedő résztvevő bizonyul itt is stabilabb kollokáltnak (fémeket). Végül ebbe a fogalmi csoportba tartozik a (4e) 'jogi érvényességet megkérdőjelez' jelentést aktiváló kollokációjelöltek kis hányada (végeredményt, kórháztörvényt), de alacsony asszociációs együtthatóval, kevés megvalósulással.

Ha a fenti csoport ellentétét, azaz a támadó résztvevő nyelvi megjelenítését tekintjük (nS+v, azaz nominális szubjektum és igealak grammatikai szerkezettel), megfigyelhetjük, hogy az elsősorban a (4c) 'fiziológiai károsodás' jelentés kialakításához kínál sémát (immunrendszere, vírus, immunendszer, kór, bacilus). Az adatok egy része a 'virtuális károkozás' jelentésen is osztozik (például vírus, amely egyaránt utalhat a biológiai és a számítástechnikai „kórokozóra”). Ezzel összekapcsolódik azonban a jelentés kiterjesztése nem humán szervezetekre (gyümölcsmoly, szürkepenész, munilia), ami arra enged következtetni, hogy a biológiai értelemben vett támadást elsődlegesen alanyesetben álló nominális kollokálttal fejezik ki a nyelvhasználók, ez a fogalmi csoport és szerkezeti séma tűnik produktívabbnak. (A 'kémiai támadás' jelentésnek is van egy előfordulása a kollokációk között, az olvadéka kifejezés, például $A$ nátrium-szulfid olvadéka megtámadja az üveget.)

A harmadik elkülöníthető almintázat a támadás eseményének körülményét teszi hozzáférhetővé ( $v+n S e t$, azaz igealak és setting fogalmi körbe tartozó, határozói esetraggal ellátott nominális). Ezt a fogalmi csoportot, illetve szerkezeti sémát kizárólag a (4e) 'jogi érvényesség megkérdőjelezése' jelentés kapcsán találjuk meg a korpusz adataiban, ami azt mutatja, hogy az igei jelentés metaforizálódásának egyik iránya erősen korrelál egy tipikus kollokációs sablonnal, illetve grammatikai szerkezettel. Mindezt érdemes összevetnünk azzal, hogy a jogi metaforizáció megjelenik ugyan v+nO sémával is (különösen a gyengébb jelöltek között), de azok a kollokációk kevéssé stabilak (alacsonyabb a kollokációs értékük, közel 2,5-es eltérés figyelhető meg az nSet és az nO legstabilabb jelöltje között), és osztoznak a sémán más jelentésekkel is.

A kollokációs adatok, a grammatikai szerkezetek és a jelentések összevetése e magasabb generalizációs szinten továbbra is azzal az eredménnyel jár, hogy az erős kombinált hipotézis nem tartható: a metaforikus jelentések nem különülnek el egyértelmű és kizárólagos nyelvi konstrukciókként. Felfedezhető azonban elkülönülés, amely komplexebb és változatosabb mintázatokat eredményez: vannak olyan fogalmi csoportok és nyelvi szerkezetek, amelyek több eltérő jelentés kifejezésének kiindulópontjai, ezek a jelentések azonban összefüggésbe hozhatók: mindegyikük a támadás fizikai aktusát helyezi a figyelem előterébe, illetve azt a résztvevőt, amely ezt az agressziót elszenvedi. (Érdekes, hogy még a 'virtuális károkozás' 
jelentés is ezt a sémát preferálja - ennek magyarázatára később még visszatérek, ezen a ponton csak annyit jegyzek meg, hogy az eredmények arra engednek következtetni: a hackertámadásokat a fegyveres erőszak mentén konceptualizáljuk.) Hasonló következtetéseket fogalmazhatunk meg a biológiai/fiziológiai metaforizáció esetében, ahol a tipikusnak tűnő séma a nominális alany megjelenése, illetve a támadó fél előtérbe kerülése. Ezzel szemben a legkevésbé fizikai értelemben vett támadási esemény, a jogi érvényesség kétségbe vonása elsődlegesen a körülmény nyelvi kifejezésével profilálódik.

Az elemzések eredményeképpen egy skála körvonalazódik, amelynek egyik végpontja az igealak szó szerinti jelentése, a másik a teljesen absztrakt, jogi értelemben vett támadás. Minél inkább az esemény fizikai jellegét, a tettleges károkozást szeretnénk kifejezni, annál nagyobb a valószínüsége annak, hogy a nominális objektumot dolgozzuk ki nyelvileg az igealak mellett. A másik szélső tartományban az elvont megtámadás környezetét specifikáljuk az igealak közvetlen környezetében. A skála köztes részén helyezhetők el azok az esetek, amelyeknél a támadás ugyan fizikai (biológiai, kémiai) károsodással jár, ám a folyamat intenzitása alacsony, lefolyása nem gyors, közvetlenül kevéssé figyelhető meg. Ekkor a konceptualizáló nagy valószínűséggel profilálja a támadó résztvevőt, megszemélyesítve teszi azt hozzáférhetővé, hogy kellően szaliens legyen a konstruált jelenetben.

\subsubsection{A megtámadja igealak metaforizációjának konstrukciói}

Az eddigiekben sikerült felismerhetővé tenni, hogy a kiválasztott igealak nem metaforikus és metaforikus jelentéseinek nyelvi megformálása a korpusz adatai alapján általánosabb sémákat követ. E sémák először a kollokációs profil nyalábszerű kategóriáiként adódtak, elmosódó határokkal, egyértelmű korrelációk nélkül, csak részlegesen elkülöníthető mintázatokként. Ami azonban a felszíni megvalósulások gazdag adatsorában pusztán felsejlö, részleges csoportosításként adódott, a konceptuális tényezőkre és az együttesen előforduló elemekre összpontosító elemzésben már sémaszinten is megkülönböztethető, és funkcionálisan, a jelentések felöl jellemezhető kategóriák rendszereként jelent meg. Folytatva az általánosítást, ezúttal azt vizsgálom, hogy az egyes jelentések milyen nyelvi konstrukciókkal fejeződnek ki a korpuszban, azaz újabb hangsúlyáthelyezéssel a metaforikus jelentést ezúttal már a kollokációkkal megragadható grammatikai szerkezetekhez társítom. Az információkat leképezési táblázatban összesítettem (Hunston-Francis 2000: 123-142 alapján), amely konstrukciók mentén elkülönítve mutatja be a tipikus kollokációkat, és tartalmazza az asszociációs értékeket (illetve a gyakoriságokat) is.

A leképezési táblázat lehetőséget ad arra, hogy a kollokálódásról szerzett adatokat egy újabb aspektusból tekintsük át, mégpedig a nyelvi megvalósítás konstrukciós sémái felől. Mindenekelőtt megállapíthatjuk, hogy adverbiális konstrukció nem alakult ki: egyetlen igen stabil kollokált jelenik meg a korpuszban módhatározóként, ám ez hapaxszerü viselkedést mutat (az összes előfordulása egyazon szövegpéldányt ismétlődéséből következik), ez magyarázza előkelő helyezését a listán. 


\begin{tabular}{|c|c|c|c|}
\hline adv/ mód & & $\mathbf{v}$ & n / landmark \\
\hline $\begin{array}{l}\text { (valamit) demonstrálva } \\
9.586 \text { / } 60\end{array}$ & & megtámadja & $a z t$ \\
\hline n / trajektor & & $\mathbf{v}$ & $\mathrm{n}$ / landmark \\
\hline $\begin{array}{l}\text { Szovjetunió } \\
4.418 / 12\end{array}$ & & megtámadja & $\begin{array}{l}\text { Finnországot } \\
5.933 / 5\end{array}$ \\
\hline $\begin{array}{l}\text { Irán } \\
4.109 \text { / } 9\end{array}$ & & megtámadja & $\begin{array}{l}\text { Afganisztánt } \\
7.259 / 14\end{array}$ \\
\hline $\begin{array}{l}\text { Németország } \\
3.622 \text { / } 20\end{array}$ & & megtámadja & $\begin{array}{l}\text { Lengyelországot } \\
6.943 / 16\end{array}$ \\
\hline n / trajektor & n / körülmény & $\mathbf{v}$ & $\mathrm{n} /$ landmark \\
\hline $\begin{array}{l}\text { (lesz olyan,) aki } \\
1.860 / 141\end{array}$ & $\begin{array}{l}\text { az Alkotmánybíróságon } \\
8.044 \text { / } 23\end{array}$ & megtámadja & $\begin{array}{l}\text { a jogszabályt } \\
4.343 \text { / } 8\end{array}$ \\
\hline $\begin{array}{l}\text { a kormányfö } \\
2.004 / 10\end{array}$ & & megtámadja & $\begin{array}{l}\text { a végeredményt } \\
5.583 / 10\end{array}$ \\
\hline $\begin{array}{l}\text { a vesztes } \\
4.869 / 10\end{array}$ & $\begin{array}{l}\text { bíróságon } \\
5.910^{\star} / 26\end{array}$ & megtámadja & $\begin{array}{l}\text { a döntést } \\
4.018 \text { / } 30\end{array}$ \\
\hline $\mathrm{n} /$ trajektor & & $\mathbf{v}$ & n / landmark \\
\hline $\begin{array}{l}\text { a vírus } \\
6.105 \text { / } 39\end{array}$ & & megtámadja & $\begin{array}{l}\text { a gépüket } \\
7.829 / 17\end{array}$ \\
\hline n / trajektor & & $\mathbf{v}$ & n / landmark \\
\hline $\begin{array}{l}\text { (a szervezet) } \\
\text { immunrendszere } \\
6.665 / 10\end{array}$ & & megtámadja & $\begin{array}{l}\text { (saját) } \\
\text { idegrendszerét } \\
5.744 \text { / } 4\end{array}$ \\
\hline $\begin{array}{l}\text { a vírus } \\
6.105 \text { / } 39\end{array}$ & & megtámadja & $\begin{array}{l}\text { az idegrendszert } \\
6.454 / 8\end{array}$ \\
\hline $\begin{array}{l}\text { a vírus } \\
6.105 \text { / } 39\end{array}$ & & megtámadja & $\begin{array}{l}\text { a sejteket } \\
5.975 / 10\end{array}$ \\
\hline n / trajektor & & $\mathbf{v}$ & n / landmark \\
\hline (klórozószer) & & megtámadja & $\begin{array}{l}\text { fémeket } \\
5.956 / 5\end{array}$ \\
\hline $\begin{array}{l}\text { olvadéka } \\
5.503 \text { / } 3\end{array}$ & & megtámadja & üveget \\
\hline n / trajektor & & $\mathbf{v}$ & n / landmark \\
\hline $\begin{array}{l}\text { a gyümölcsmoly } \\
5.494 / 3\end{array}$ & & megtámadja & a gyümölcsöt \\
\hline
\end{tabular}

3. táblázat

A megtámadja igealak konstrukcióit összesítő leképezési táblázat.

A csillaggal jelölt esetekben a nagyobb kollokációs ablak torzította az eredményt. A kifejezések alatti első számadat a logDice érték, a második a gyakoriság.

Más azonban a helyzet azzal a szerkezettel, amelyben a támadás mindkét végrehajtója, azaz - kognitív nyelvtani terminusokkal - a trajektor (elsődleges figura) és a landmark (másodlagos figura) is ki van dolgozva. A (4b) 'fegyveres támadás' jelentés esetében jellemzően a konstrukció landmark komponense stabilabb kollokációs partner. Ez figyelhető meg a (4c) 'fiziológiai károsodás' jelentésének kiterjesztéseként előálló 'virtuális károkozás' jelentés esetében is, továbbá a 'kémiai károsodás' jelentés kapcsán is (noha jóval kisebb a különbség a konstrukció komponenseinek asszociációs értéke között, ezek tehát kevésbé stabil 
konstrukciós mintázatok). A (4c) hagyományos jelentésében, 'fiziológiai károsodás' értelemben, humán résztvevőknél viszont a trajektor komponens tűnik stabilabb kollokációjelöltnek. Ezt a sablont követik a 'nem humán biológiai károsodás' jelentését profiláló kollokációk is.

Végül vannak olyan szerkezetek is, amelyekben a legstabilabb kollokációs partner a körülményt kifejező nominális: mind a trajektorhoz, mind az objektumként profilálódó landmarkhoz képest elsődleges tagja a szerkezetnek. Ez a konstrukció jár együtt leginkább a (4e) jogi metaforizációjával.

Megfigyelhető tehát három konstrukciós mintázat. Az egyik az objektum konstrukció: elsődlegesen a 'fegyveres támadás' jelentést fejezi ki, de minden olyan további, metaforizálódó jelentés megformálására is alkalmas, amely a károsodás/károkozás eseményének fizikai jellegére (a tettlegességre), nagyfokú intenzitására, és az agressziót elszenvedő résztvevőre irányítja a figyelmet. ${ }^{11} \mathrm{~A}$ másik mintázat a szubjektum konstrukció, amely a metaforikus konstruálás fontos eszköze: a nyelvhasználó ezzel a konstrukcióval tudja kifejezni a károsodás folyamatának intenzitását és visszafordíthatatlanságát, annak ellenére, hogy az közvetlenül nem vagy nehezen észlelhető (csupán tünetein és eredményén keresztül). A harmadik konstrukció a körülmény konstrukció: a nyelvhasználónak ezzel a sémával nyílik lehetősége arra, hogy egyértelmüen jelezze eltávolodását az elsődleges jelentéstől az absztrakt, nem fizikai támadási aktus irányába.

Az adatok e konstrukciók viszonyára is rálátást engednek bizonyos mértékig: a szubjektum konstrukció elsődlegesen a fiziológiai/biológiai metaforizálódásra foglalódott le, éppen ezért amikor e metaforikus jelentés további kiterjesztése megjelent ('virtuális károkozás'), azt a konstrukció szintjén is el kellett különítenie a nyelvhasználónak. Részben ez, részben a már említett terror-, illetve fegyveres támadás analógia motiválhatta azt a fejleményt, hogy az interneten történő támadások kifejezésére az objektum konstrukció vált bevett megoldássá. ${ }^{12}$

${ }^{11}$ Fontos megjegyezni, hogy a feltárt konstrukció nem azonosítható magával a metaforikus jelentéssel: az egyik egy megfigyelhető stabil kollokációs mintázatot motiváló sematikus szerkezet, a másik egy szemantikai séma átrendeződésével megvalósuló figuratív jelentés (pontosabban többé-kevésbé sematikus típusjelentés). Úgy tűnik azonban, hogy bizonyos sematizálódó jelentések gyakran tipikus kollokációs mintázatokban valósulnak meg, vagyis tipikus konstrukciókat preferálnak. E szemantikai preferencia pedig a konstrukció további alkalmazásba vételét is motiválhatja, és a metaforikus konstruálás kiindulópontjává teheti azt.

${ }^{12} \mathrm{~A}$ tanulmány egyik anonim lektora felveti, hogy a 'virtuális károkozás' jelentés és az objektum konstrukció szoros kapcsolatának hátterében a támadás célpontjának rendkívül korlátozott kifejezési lehetősége áll, nevezetesen az, hogy ez esetben a tárgy lényegében csak gépet lehet. Noha ezt mindenképpen ellenőrizni kell nagyobb mintán, és lehetőség szerint a metaforikus jelentés kialakulásának folyamatát feltérképezve, a felvetés értelmében nem egy metaforikus jelentés konstrukciós preferenciájáról, hanem sokkal egyszerübb megszilárdulási jelenségről van szó, melynek során a gépet tárgy idiomatikusan rögzült ebben a jelentésben. Ezzel a lehetőséggel számolni kell, még akkor is, ha a kollokációs mintázatok feltárása nem zárja ki az idiomatizálódás lehetőségét. A kérdést leginkább a gépet státusának eldöntésével lehet megválaszolni, amely egyúttal kollokáció és idióma viszonyának újragondolását is szükségessé teszi. 


\subsection{További eredmények: megrohanja, megrohamozza}

A korpuszvezérelt vizsgálat feltárhatóvá teszi azokat a nyelvi szerkezeteket, amelyek az egyes elkülöníthető metaforikus jelentések kifejezésére formálódnak meg és stabilizálódnak a nyelvhasználatban. A vizsgálatban a kollokációk kvantitatív elemzése, továbbá az egyre magasabb szinten megvalósuló általánosítás kvalitatív lépései elkerülhetővé teszik az idealizációt a metafora leírásában, a következetesen érvényesített módszertan pedig csökkenti az intuíció szerepét a metaforizáció elemzésében, hiszen ha e jelentések a grammatikai szerveződés szintjén válnak meghatározhatóvá és megkülönböztethetővé (a profilmeghatározó igei jelentés átrendeződése mentén), akkor a konstrukció elemzése nagyban hozzájárul a metaforák azonosításához. A megtámadja igealak változatos korpuszbeli előfordulásai megfelelő anyagnak bizonyultak a kutatáshoz. A módszert azonban további szóalakokon kell kipróbálni, hogy az eredmények ellenőrizhetővé váljanak. Ezért a következőkben két ritkább, de az eddigi jelentésekkel rokonítható szóalak, a megrohanja és a megrohamozza kollokációs profiljának elemzését végzem el, amely egyúttal a kutatás nyelvtanvezérelt jellegére vonatkozóan is további reflexiókat tesz lehetővé. (A két kiválasztott igealak alacsony gyakorisága, korlátozott kollokációs mintázata miatt ezeket az eredményeket együtt közlöm.)

\subsubsection{A megrohanja és a megrohamozza kollokációs profilja}

A megrohanja kifejezés 89 előfordulással jelenik meg az MNSz2 korpuszában, összesen 7 kollokációjelölttel alkotott szerkezetet vizsgáltam. A legmagasabb asszociációs érték 6,570 (riporterek), ez azonban nem alkot az igealakkal közvetlen szintaktikai szerkezetet (például azonnal megrohanja a versenyzót a riporterek hada); a legalacsonyabb 1,240 (hirtelen - például megrohanja hirtelen tündökló léte). A vizsgált szóalak ritkasága indokolta a korábbinál alacsonyabb logDiceküszöb meghúzását.

A megrohamozza kifejezés még ritkábban fordul elő az MNSz2 korpuszában, összesen 42 találatot tudtam elemezni. Ez 5 kollokációjelölt részletes vizsgálatára adott módot, a legmagasabb logDice-érték 11,193 (leárazáskor - a tömeg leárazáskor megrohamozza az üzleteket), a legalacsonyabb 2,457 (tömeg - a tömeg megrohamozza a tartományi kormányzóság épületét). Mivel igen kevés előfordulással rendelkezik a szóalak a teljes korpuszban, a ritka szerkezetek, hapax jellegü adatok torzító hatása jelentkezik. Mégis a két igealak együttes elemzése fontos lehet mind a korpuszvezérelt kutatás eredményeinek árnyalásában, mind a nyelvtanvezérelt elméletalkotás részletezésében.

Az Értelmező Kéziszótár a következő jelentéseket különíti el a megrohan igető kapcsán. ${ }^{13}$

a. 'Rohanva v. rárontva megtámad vkit, vmit.'

b. 'Rohanva, tódulva meglep, ellep vmit.'

Az ige poliszémiája tehát az alapjelentésen túl egy metaforikus kiterjesztést is mutat, amelyben a támadás aktusa nem kerül előtérbe, de az interakció intenzitása és totalitása erősen profilálódik. Ez a jelentésleírás azonban nem kielégítő a konkrét esetek elemzéséhez.

${ }^{13}$ Az adatok forrása: www.szotar.net, az elérés időpontja 2017. 04. 27. 
(8) a. azonnal megrohanja a versenyzőt a riporterek hada

b. A szomáliai tömeg megrohanja Durant helikopterbalesetének helyszínét.

c. a palesztin népet megrohanja a félelem

Nem egyértelmű például, hogy a (8a) példa az alapjelentés, vagy a metaforikus kiterjesztés megvalósulásaként értelmezendő-e, hiszen a támadás aktusa ebben az esetben nem jelent fizikai agressziót, ugyanakkor a konstruálásban mégis ez az aspektus dominál (ezt erősíti a hada nominális megjelenése is), vagyis a példa valahol félúton helyezkedik el az alapjelentés és a metaforizálódás között. $A(8 b)$ esetében az elemzői intuíció szerint a (7b) jelentés aktiválódik, ugyanakkor ez nem elsősorban a folyamat trajektorának kidolgozásából következik (tömeg), az ugyanis még megvalósíthatná az alapjelentést is (például a tömeg megrohanja a törvényhozás épületét), vagyis nem figyelhető meg a séma átrendeződése a jelentésképzés során. Azaz itt is vizsgálni kell, hogy az összetett (kompozitum)szerkezet mely összetevője kezdeményez metaforizációt. Hasonló probléma lép fel a (8c) példa kapcsán, ahol a landmark kidolgozása (népet) még nem teszi metaforikussá a szerkezetet (nem vár el sémarekonfigurációt), sokkal inkább a trajektoré (félelem).

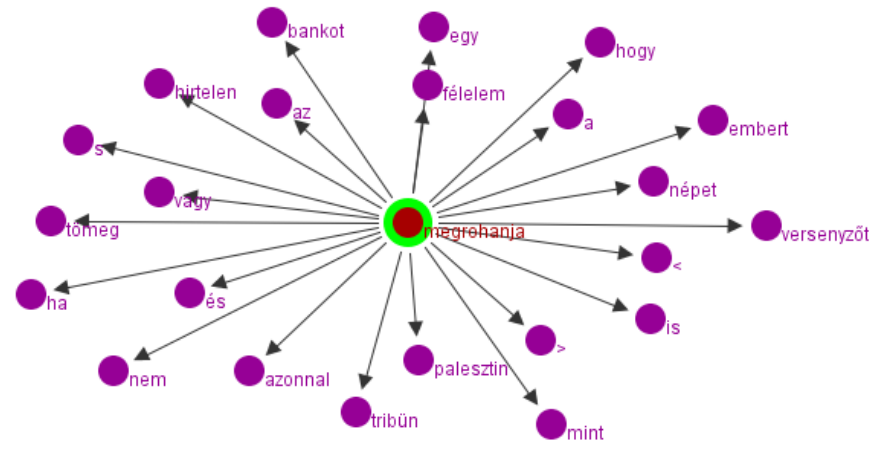

2. ábra

A megrohanja szóalak kollokációjelöltjei 1,2 logDice küszöbérték mellett

A kollokációs profilt a megrohanja igealak esetében a 2. ábra mutatja be. Még kevés adatnál is megfigyelhető rétegekbe rendeződés: a legstabilabb kollokáltak között a népet szóalak mellett ott szerepel a félelem kifejezés is, amelyek (8c) példában fordulnak elő együtt. Ez arra enged következtetni, hogy a jelentés ambivalenciája (megrohanja a népet - szó szerint, vagy metaforikusan?) a trajektor kidolgozásával, kollokálódásával oldható fel. Továbbá az is feltűnő lehet, hogy a kifejezés elsődleges profilját kidolgozó, illetve azt nem változtató (legfeljebb kiterjesztő) kollokáltak (tömeg, embert) kevésbé stabilak, mint a metaforizálódást kezdeményezők (félelem, bankot).

A megrohamozza kifejezés metaorizálódásának bemutatását ismét először a szótárban rögzített jelentések segítségével szemléltetem. ${ }^{14}$

${ }^{14}$ Az adatok forrása: www.szotar.net, az elérés időpontja 2017. 04. 27. 

a. '<Katonaság> rohamozva megtámad vkit, vmit.'
b. '<Tömeg> megrohan vkit, vmit.'
c. 'Kérdésekkel vagy kérésekkel megostromol.'

A ritkább kifejezés árnyaltabb jelentésleírással jelenik meg a szótárban, ezúttal a fizikai agressziót előtérbe helyező alapjelentés (9a) és annak metaforikus kiterjesztése (9b) elkülönülő jelentésekként jelennek meg. A példák alapján ez indokolt lenne a megrohan igető esetében is. További furcsaság, hogy a korábbi (8a) példa ez esetben a (9c) jelentés megvalósulásaként lenne értelmezhető. (A (9c) jelentésre az elemzett adatok között nem volt példa.) Mindez azt mutatja, hogy a szótári adatok legfeljebb kiindulópontjai lehetnek a metaforizáció elemzésének, a jelentések elkülönítését azonban érdemes árnyalni a korpuszvezérelt vizsgálat során, hogy elkerülhetővé váljanak a különböző fokú, részben önkényesnek tűnő általánosítások.

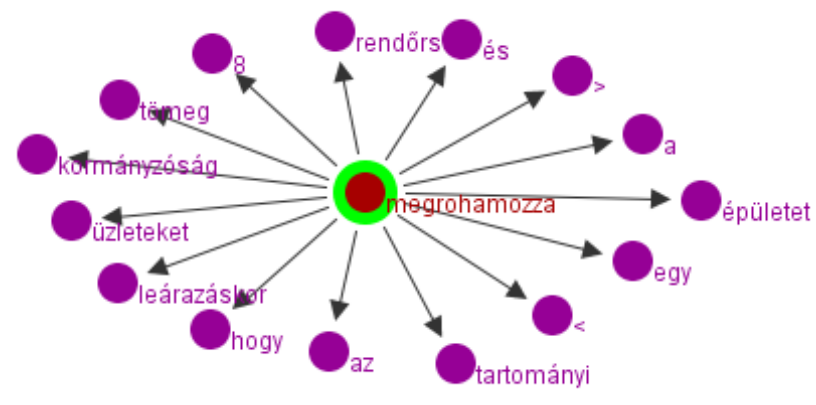

3. ábra

A megrohamozza szóalak kollokációjelöltjei 2,4 logDice küszöbérték mellett

A megrohamozza MNSz2-beli előfordulásainak kollokációs profilját a 3. ábra mutatja. Itt már nem figyelhetünk meg rétegekbe rendeződő mintázatot, az alacsony gyakoriságból következően. Vagyis bár megkülönböztethetők az egyes jelentések az ige poliszém struktúrájában, ezek a nyelvhasználatban nem szimbolizálódnak elkülönülő kollokációs almintázatokkal, sablonokkal, legalábbis a GraphColl analízise alapján. Megállapítható tehát, hogy a korpuszvezérelt kutatáshoz olyan szóalakokat érdemes választani, amelyek kellően magas gyakorisággal rendelkeznek a korpuszban ahhoz, hogy az adatok alapján a nyelvhasználatban végbemenő kollokálódási folyamatokra, illetve az ezek nyomán kialakuló konstrukciókra következtethessünk. Természetesen más korpuszok is felhasználhatók adatgyűjtésre, hogy a ritkább kifejezések metaforizálódásának grammatikai vonatkozásait közvetlenül vizsgálhassuk. A kutatás jelenlegi fázisában az eredmények még korpuszfüggőnek tekinthetők. Ám még ilyen kevés adat esetében is megfigyelhető, hogy a kollokáltak az ige trajektorát, tárgyi landmarkját, illetve körülményét dolgozzák ki, azaz e három lehetséges almintázat mentén tehetünk kísérletet a metaforizálódás grammatikai elemzésére. 
5.2.2. Fogalmi csoportosítás és konstrukciók a megrohanja és a megrohamozza esetében

A kollokációs profil feltérképezése finomítható az igékkel szimbolizált folyamatok fogalmi struktúrájának bemutatásával.

\begin{tabular}{|l|l|l|l|}
\hline Kollokációjelölt & logDice & Mintázat & Fogalmi csoport \\
\hline népet & 5.312 & $\mathrm{v}+\mathrm{nO}$ & Akit/amit megrohannak \\
versenyzót & 5.303 & $\mathrm{v}+\mathrm{nO}$ & Akit/amit megrohannak \\
félelem & 4.697 & $\mathrm{nS}+\mathrm{v}$ & Aki/ami megrohan \\
bankot & 3.664 & $\mathrm{v}+\mathrm{nO}$ & Akit/amit megrohannak \\
tömeg & 1.718 & $\mathrm{nS}+\mathrm{v}$ & Aki/ami megrohan \\
hirtelen & 1.240 & $\mathrm{v}+\mathrm{adv}$ & A megrohanás módja \\
\hline
\end{tabular}

4. táblázat

A megrohanja igealak stabil kollokáltjainak fogalmi csoportosítása

Szürkével jelöltem a metaforikus adatokat.

A megrohanja legstabilabb kollokáltja (népet) önmagában nem kezdeményez sémaátrendeződést, azaz metaforizációt az igei jelentés kialakításában. Ugyanakkor az eseményt elszenvedő résztvevő két esetben is stabilan kollokálódik, és metaforikus jelentést kezdeményez: a versenyzôt kapcsán felvethető, hogy a (7a-b) mellett új metaforikus kiterjesztést érdemes azonosítani, a (9c) mintájára; a bankot kollokált pedig egyértelműen a (7b) kiterjesztés megvalósulása. Érdekesebb a félelem nominális: viszonylag stabil kollokációjelölt a mintában, ugyanakkor a cselekvést végrehajtó résztvevőt szimbolizálja, vagyis egyfelöl más nyelvtani szerkezetet valósít meg, másfelöl az igével jelölt folyamat fogalmi kidolgozását is másként, intenzívebb sémaátrendeződéssel teszi lehetővé.

Az 5. táblázatból kiderül, hogy nincsenek jól elkülöníthető konstrukciók, az ige metaforikus használata tehát ezúttal kevésbé rendeződik ,jólformált” és konvencionális nyelvtani szerkezetekbe. Az objektum konstrukció dominál, és az esetek egy részében valóban elegendő is a másodlagos figura kidolgozására stabilizálódott kollokált, hiszen a bank és a versenyző „megrohanása” önmagában a sematikus igei jelentés átrendezésével jelölhető nyelvileg. A szó szerinti és a metaforikus jelentés kontinuuma tehát elsősorban az objektum konstrukcióval fejeződik ki: egy formai jelölő több jelentést is megvalósít, nincsenek különböző forma-jelentés párok a nyelvhasználatban az igealak esetében. Ám amennyiben az objektum konstrukció nem elegendő a metaforizációhoz, megjelenik a szubjektum konstrukció is (a félelem a példa erre). Úgy is fogalmazhatunk, hogy a viszonylag ritka igealak metaforikus jelentéseinek azonosítása és a szó szerintitől való megkülönböztetése megoldható egyetlen stabilizálódó konstrukció, illetve az azt megvalósító felszíni kollokációk révén. Ha azonban egyértelmüsíteni akarjuk a metaforizálódást, és a folyamat elszenvedőjének kidolgozása nem elégséges, alkalmazhatunk szubjektum konstrukciót is. Erre egyetlen adat van, amely nem alkalmas általánosabb következtetések megfogalmazására, mégis azt láthatjuk, hogy a szubjektum konstrukció nem csupán feloldja a jelentés ambivalenciáját, hanem a metaforizáció intenzitásának növekedését is jelöli, mintegy új metaforikus jelentést ('mentálisan eluralkodik vmi vkin') téve lehetővé. 


\begin{tabular}{|lll|}
\hline $\mathbf{n}$ / trajektor & $\mathbf{v}$ & $\mathbf{n}$ / landmark \\
\hline $\begin{array}{l}\text { a félelem } \\
4.697 \text { / 16 }\end{array}$ & megrohanja & $\begin{array}{l}\text { a népet } \\
5.312 / 16\end{array}$ \\
\hline $\mathbf{n}$ / trajektor & $\mathbf{v}$ & $\mathbf{n}$ / landmark \\
\hline $\begin{array}{l}\text { a tömeg } \\
1.718 \text { / 4 }\end{array}$ & megrohanja & a helyszínt \\
\hline $\mathbf{n}$ / trajektor & $\mathbf{v}$ & $\mathbf{n}$ / landmark \\
\hline a riporterek hada & megrohanja & a versenyzót \\
& & 5.303 / 4 \\
\hline $\mathbf{n}$ / trajektor & $\mathbf{v}$ & $\mathbf{n}$ / landmark \\
\hline mindenki & megrohanja & a bankot \\
& & 3.664 / 3 \\
\hline adv / mód & $\mathbf{v}$ & $\mathbf{n}$ / landmark \\
\hline $\begin{array}{l}\text { hirtelen } \\
\text { 1.240 / 4 }\end{array}$ & megrohanja & a helyet \\
\hline
\end{tabular}

5. táblázat

A megrohanja igealak konstrukcióit összesítő leképezési táblázat

A megrohamozza igealak jelentéseinek feltérképezése során a metaforizáció kontinuitása még jobban érvényesül. A 6. táblázatból kiderül, hogy a stabil kollokáltak szinte egytől egyig a rohamot elszenvedő résztvevő megjelölését végzik el.

\begin{tabular}{|l|l|l|l|}
\hline Kollokációjelölt & logDice & Mintázat & Fogalmi csoport \\
\hline leárazáskor & 11.193 & $\mathrm{adv}+\mathrm{v}$ & A megrohamozás körülménye \\
üzleteket & 5.284 & $\mathrm{v}+\mathrm{nO}$ & Akit/amit megrohamoznak \\
épületét & 3.925 & $\mathrm{v}+\mathrm{nO}$ & Akit/amit megrohamoznak \\
épületet & 2.745 & $\mathrm{v}+\mathrm{nO}$ & Akit/amit megrohamoznak \\
tömeg & 2.457 & $\mathrm{nS}+\mathrm{v}$ & Aki/ami megrohamoz \\
\hline
\end{tabular}

6. táblázat

A megrohamozza igealak stabil kollokáltjainak fogalmi csoportosítása. Szürkével jelöltem a metaforikus adatokat.

Feltűnő tehát egyfelől, hogy az objektum konstrukció a (9a) és a (9b) jelentést egyaránt kifejezhetővé teszi, a metaforikus jelentés ezúttal sem rendeződik látványosan konstrukciós kategóriákba a nyelvhasználatban. Érdekes továbbá, hogy nagyon kis mértékü a szubjektum konstrukció megjelenése a mintában: noha a tömeg nominális a (9b) metaforikus kiterjesztést valósítja meg, más példa a konstrukcióra nincsen, a meglévő példa pedig nem kezdeményez intenzív metaforizációt. Vélhetően az motiválja mindezt, hogy a megrohamoz ige alapjelentése specifikus, önmagában előtérbe helyezi a roham útján történő fizikai agressziót, ezért kevéssé alkalmas más jellegű (fiziológiai/kémiai/biológiai/mentális) állapotváltozások kifejezésére. Ugyanakkor a legstabilabb kollokált nem az objektum konstrukciót, hanem a megtámadja esetében már megfigyelt körülmény konstrukciót valósítja meg, határozottan kezdeményezve a (9b) metaforikus kiterjesztéshez szükséges sémaátrendeződést. 


\begin{tabular}{|lll|}
\hline $\mathbf{n}$ / trajektor & $\mathbf{n}$ / mód & $\mathbf{v}$ \\
\hline a tömeg & leárazáskor & megrohamozza \\
2.457 / 5 & 11.193 / 4 & \\
\hline $\mathbf{n}$ / trajektor & $\mathbf{v}$ & $\mathbf{n}$ / landmark \\
\hline a tömeg & megrohamozza & az üzleteket \\
2.457 / 5 & & 5.284 / 4 \\
\hline $\mathbf{n}$ / trajektor & $\mathbf{v}$ & $\mathbf{n}$ / landmark \\
\hline a tömeg & megrohamozza & (a tartományi kormányzóság) épületét \\
2.457 / 5 & & 3.925 / 3 \\
\hline $\mathbf{n}$ / trajektor & $\mathbf{v}$ & $\mathbf{n}$ / landmark \\
\hline a rendörség & megrohamozza & az épületet \\
& & 2.745 / 3 \\
\hline
\end{tabular}

7. táblázat

A megrohamozza igealak konstrukcióit összesítő leképezési táblázat

A leképezési táblázat alapján megállapítható, hogy az elsődleges metaforikus konstrukció a megrohamozza igealak esetében a körülmény konstrukció. Az objektum konstrukció és a szubjektum konstrukció jóval csekélyebb stabilitást mutatnak.

(10) a tömeg leárazáskor megrohamozza az üzleteket

A (10) korpuszbeli példában három kollokált is együtt fordul elő, ezek asszociációs értéke azonban nem egyforma. A legmagasabb értékkel a körülményt kifejező kollokált bír, amely egyúttal a leginkább specifikálja az elemi mondattal kifejezett (vásárlási) eseményt. A megrohamozza igealak szubjektum konstrukciója nem vesz részt intenzív metaforizálódásban; az objektum konstrukció alkalmasabb a metaforikus jelentés kezdeményezésére, ám a nyelvhasználó igazán a körülmény konstrukcióval tudja jelölni, hogy az igei jelentés metaforikus kiterjesztését (a séma átrendeződését) kezdeményezi. A (10) mondat elemzése a kvantitatív adatok tükrében azt mutatja, hogy míg a gyakori igealakok esetében a konstrukciók jobban stabilizálódnak a metaforizáció irányai mentén, addig a ritkább igealakoknál a stabil kollokációk, és a hátterükben kibontakozó konstrukciók inkább a szó szerinti jelentéstől való elmozdulást, azaz a jelentés metaforikus kiterjesztését hivatottak jelölni. Az adatok felöl tekintve az is megállapítható, hogy míg a magas gyakoriságú kifejezések esetében gazdagabb és termékenyebb sematikus konstrukciók alakulnak ki, a ritka szóalakok vizsgálata kevés, de kiugróbb (magas kollokációs együtthatóval jellemezhető) kollokáltat mutat fel, mint ez esetben a leárazáskor, vagyis az alacsony gyakoriságú kifejezések hajlamosabbak az idiomatizálódásra a korpusz által reprezentált nyelvhasználatban. Ez pedig azért fontos, mert indokolja a ritka alakok további vizsgálatát.

\section{6. Összegzés}

Ebben a tanulmányban arra tettem kísérletet, hogy a metaforikus jelentés újszerü megközelítését kezdeményezzem. A metaforát olyan nyelvi szerkezetnek tekintem, amely bizonyos kifejezések együttes előfordulásának gyakoriságával stabilizálódó szemantikai struktúra. Másfelől olyan grammatikai szerkezetként értelmezem, 
amelynek műveleti feldolgozása során a jelentésükben integrálódó komponensek kezdeményezik a porfilmeghatározó komponens fogalmi profiljának megváltozását, vagyis szemantikai sémájának átrendeződését. A tanulmány egyik hozadéka, hogy összekapcsolja a metaforikus jelentés szemantikai, korpusznyelvészeti és grammatikai megközelítéseit. A másik hozadéka egy korpusz- és nyelvtanvezérelt módszertan lefektetése. A tanulmányban idézett, hivatkozott és összekapcsolt elemek önmagukban tehát nem feltétlenül újak a kognitiv nyelvészeti metaforakutatásban. Mégis újnak mondható ezek együttes müködtetése, összehangolása, továbbá az, hogy a magyar nyelv leírásában ezidáig nem alkalmaztak ilyen metodológiát a metaforák elemzésére. Ezért a módszer további finomításától, újabb kifejezésekre történő alkalmazásától hosszabb távon a magyar nyelv jellemző metaforikus mintázatainak átfogó bemutatása várható.

A kutatás korpuszvezéreltségéből adódóan az eredmények mind a szótári jelentésadást, mind a fogalmi metaforák leírását árnyalhatóvá teszik. A korpuszban előforduló kollokációk alapos elemzésével ellenőrizhető, és szükség esetén revideálható a szótárban elkülönülő jelentések rendszere. A megtámad esetében például a (4a) és a (4b) jelentések nem rendeződnek különböző kollokációs almintázatokba, mindegyikük az objektum konstrukcióval szimbolizálódik, ezért a nyelvhasználati adatok e két jelentés szoros kapcsolatára mutatnak rá, a metonimikus kiterjesztés még nem korrelál új konstrukció kiemelkedésével. A (4c) és a (4e) viszont határozott konstrukciós preferenciát mutat, amely korrelál jelentésük metaforikusságával. (A (4d)-re nem volt jellemző adat a vizsgált mintában.) A megrohan esetében javasolható a szótári jelentésadás bővítése 'kérdésekkel, kérésekkel intenzíven fordul vkihez' jelentéssel, továbbá a (7b) kiegészítése a mentális/emocionális állapotváltozással. A megrohamoz ugyanakkor jóval szűkebb kollokációs profilt mutat, mint ami a szótári jelentésadásból következne, így felvethető a szótári jelentések, különösen a (9c) újragondolása. Látható, hogy a korpuszvezérelt kutatás visszaszorítja mind az elemzői intuíciót, mind a túlzott idealizációt a szemantikai leírásban.

Ugyanezt mutatja az eredmények áttekintése a fogalmi metaforák felöl. Amennyiben elfogadjuk az érvényességét egy olyan metaforikus leképezésnek, amely az egyénben bekövetkező állapotváltozást a TÁMADÁs (kívülről érkező fizikai agresszió) konceptuális tartományával teszi hozzáférhetővé, a korpuszvezérelt kutatás nagyban finomítja ennek a leképezésnek a megvalósulási lehetőségeit az állapotváltozás függvényében. Ha ugyanis biológiai/fiziológiai változásról van szó (továbbá, ha nem humán entitás állapotáról van szó), akkor a magyar nyelvben a megtámadja igealak tűnik elsődlegesnek a konstruálásban. Ezzel szemben, ha az állapotváltozás mentális jellegü, akkor a megrohanja kollokációi érvényesülnek. A jogi érvényesség megkérdőjelezését tipikusan a megtámadja alakkal fejezzük ki a vizsgált szóalakok közül, míg a tágabb, episztemológiai értelemben vett kérdésessé tételre inkább a megrohanja alkalmas. A megrohamozza nem az aktus jellegét, hanem intenzitását és irányulását profilálja, ezért más mintázatokban vesz részt, noha jelentése ugyancsak a TÁMADÁs konceptuális tartományba tartozik.

A kutatás nyelvtanvezérelt jellege kapcsán a következő eredmények születtek. Jól látszik egyfelöl, hogy a metaforizálódást nem egyetlen tényező kezdeményezi: sokkal inkább metaforikus konstrukciókban érdemes gondolkodni (szubjektum, objektum és körülmény konstrukció a vizsgált adatoknál), amelyek bizonyos komponensei (a korpuszbeli kollokáltak, amelyek a konstrukcióban egy-egy jellemző 
fogalmi csoportot, az igében jelölt esemény egy-egy aspkektusát jelölik alanyként, tárgyként, határozóként) bizonyos típusú metaforikus jelentések (mint pl. 'fiziológiai károkozás' vagy 'jogi támadás') kifejezésére konvencionálódnak. ${ }^{15}$ Vagyis azok az elméleti modellek, amelyek egy grammatikai szerkezet egyetlen tényezőjére (általában a fogalmi autonómia/függőség szempontjára) vezetik vissza a metaforizálódást (azaz lexámaközpontú megközelítést alkalmaznak), nem számolnak azzal a ténnyel, hogy egy kifejezés jelentése többféleképpen, több különböző, de azonos jellegü komponens mentén metaforizálódhat, a nyelvhasználatban pedig ezek a kialakuló konstrukciók egymással is kapcsolatban állnak, és hatnak egymásra. Jól mutatja ezt, hogy a megtámadja igealak esetében az objektum konstrukció mind a szó szerinti, mind a nem metaforikus (metonimikusan kiterjesztett) jelentés ('fegyveres támadás'), mind pedig más metaforikus jelentések ('kémiai károsodás', 'virtuális károkozás') kifejezésére begyakoroltnak tűnik. Ráadásul ez a konstrukció részt vesz további metaforizációban is, ám azokban az esetekben egy másik konstrukció összetevője bizonyul erősebb kollokáltnak, vagyis az kezdeményezi a metaforizálódást. A metaforikus jelentés tehát nem egyetlen tényező megléte esetén aktiválódik, különböző konstrukciós sablonok állnak a nyelvhasználó rendelkezésére, és a gyakori, ismétlődő, bizonyos jelentésekkel inkább asszociálódó mintázatokat választhat az aktuális metafora nyelvi megformálására. Ezek azonban mind választások, a mintázatoktól el is lehet térni, és új mintázatok is formálódhatnak a gyakoriság mentén. Mindebből az is következik, hogy egy nyelvtani szerveződésből kiinduló, a korpuszbeli gyakoriságokat és asszociációs erősséget elemző vizsgálattól mintázatok, különböző mértékében sematikus szerkezetek, illetve preferenciák és konstruálási lehetőségek megkülönböztetése, felmérése várható, nem pedig jól formált, prediktabilitást megalapozó rendszer modellálása. Éppen ezért e kutatás a metafora azonosítása terén is azzal lépett elöre, hogy ráirányította a figyelmet a kollokációs sablonok, illetve a konstrukciók jelentőségére.

A kutatásban voltaképpen a metaforizáció grammatikai kontinuumának köztes tartományát térképeztem fel. A skála egyik végpontja a teljesen új, innovatív metaforikus szerkezetek megjelenése (pl. demonstrálva megtámadja, hirtelen megrohanja), amelyek még nem rendeződtek sematizálható mintázatba, így nem magyarázhatók semmilyen módon általános összefüggésekkel. A skála másik végpontja az idiomatizálódás (I. Deignan 2005), amikor egy rögzült szókapcsolat/szószerkezet állandósul egyetlen metaforikus jelentés kifejezésére (pl. leárazáskor megrohamozza). E két végpont, azaz a teljesen szabad variálódás és a teljesen kötött grammatikai forma közötti gazdag tartományba kínált betekintést a kutatás: itt formálódnak és stabilizálódnak ugyanis a nyelvi szerkezetek (az alapige jelentésének specifikus jellegétől és a használat gyakoriságától függően), de ezek valóban csak sablonok, nem pedig teljesen konvencionális szerkezeti sémák. $\mathrm{E}$ tekintetben a kutatás az erős kombinált hipotézist nem igazolta, hiszen nem lehet egyértelmű és kizárólagos konstrukcionálódást bemutatni a metaforikus jelentések körében. Az azonban vitathatatlan, hogy a metaforizálódás grammatikai kötöttségek kialakulásával jár (Deignan 2005: 145), és a gyenge kombinált hipotézis

\footnotetext{
${ }^{15}$ Ez fontos eredmény a korábbi kutatásokat (Simon 2016) tekintve is: ott még az elnagyolt trajektor kidolgozás és landmark kidolgozás szerepelt két önálló metaforizációs kategóriaként, ezeket a jelen vizsgálat nagyban finomítja.
} 
valóban igazolható az elemzések révén, ám kutatás egyik fontos eredménye, hogy - az intenzív idiomatizálódásra hajlamos ritka kifejezéseket leszámítva - a véletlenszerű, csupán a felszíni kollokációs profilban megmutatkozó egyedi rögzüléseken túl általánosabb konstrukciós sémák is azonosíthatók. Ezért a vizsgálat eredményei egy újabb felvetés, a köztes kombinált hipotézis (I. Hunston-Francis 2000: 86) megfogalmazásával és tézisként történő bemutatásával foglalhatók össze.

A metaforikus kifejezések szerveződésének köztes kombinált tézise: a metaforikus jelentés nyelvi megformálásában a kollokálódó kifejezések nagyobb része koherens mintázatot alkot, azaz a nyelvhasználatban kialakulnak olyan stabil kollokációs mintázatok, és ezek nyomán sematikus konstrukciók, amelyek összekapcsolódnak bizonyos metaforikus jelentések kifejezésével, fenntartva ugyanakkor a teret a szabad nyelvi innovációnak és a megmerevedő nyelvi szerkezeteknek is.

A vizsgálat módszertani célja volt a professzionális elemzői intuíció visszaszorítása is. Általános, nem e tanulmányra korlátozódó belátása a metafora kognitív nyelvészeti kutatásának, hogy ezt az intuíciót legfeljebb csökkenteni lehet, teljesen felszámolni nem. Amennyiben igazolható lett volna az erős kombinált hipotézis, úgy a metaforikus jelentés keresésének helyébe konkrét konstrukciók keresése lett volna állítható, amely - megfelelően kidolgozott keresőprogram alkalmazásával teljes mértékben automatizálhatóvá tehetné a kutatást. A tanulmány kiemelkedő eredménye, hogy sikerült rámutatni arra: elvi korlátai vannak az automatizálásnak, hiszen a metaforizáció kontinuumának mindig lesznek olyan tartományai, amelyek a szabad innováció és variálódás felé nyitottak, így nem megjósolható adatokat eredményeznek. Ugyanakkor a másik végpont felé haladva egyre jobban ellenőrizhető a metaforikus jelentés azonosítása és elemzése. A nyelvtanvezérelt vizsgálat kimutatta, hogy a profilmeghatározás jelensége, illetve a sémaátrendeződés hatékony indikátora a metaforizálódásnak, a kollokálódás feltárása pedig a tipikus sémaátrendeződések feltérképezését teszi lehetővé, a konstrukciós sablonok leírásán keresztül. Mindez új annotálási lehetőségekhez vezet (például a keretszemantika módján annotálhatjuk korpuszunkban az igei folyamat résztvevőinek fogalmi csoportjait, és a korpuszvezérelt kutatás révén e csoportokra keresve könnyebben szürhetők a metaforikus szerkezetek). Az is fontos eredmény, hogy minél inkább eltávolodik a konceptualizáló a szó szerinti jelentéstől, annál valószínűbb, hogy az igealak mellett ki lesz dolgozva annak inherens sematikus figurája. Vizsgálandó, hogy a további másodlagos figurák < landmark < trajektor hierarchia a kollokáltak esetében az egyre intenzívebb metaforizálódásnak felel-e meg, de a vizsgálat adataiból úgy tűnik, hogy ez a hierarchia áttételesen érvényes: alapvetően e séma mentén formálódnak a metaforikus kollokációk, ám ha a trajektor már lefoglalódott, akkor egy további másodlagos figura veszi át a metaforikus specifikálás funkcióját. Az itt bemutatott kutatás tehát lehetővé teszi, hogy egyrészt új korpusznyelvészeti módszereket próbáljunk ki a metaforák annotálására és keresésére, másrészt hogy ellenőrizhető módon soroljunk be egyes szerkezeteket a metafora címkéje alá, illetve differenciáltabban és az empíriával összhangban mutassuk be az adott szóalak metaforizálódásának tendenciáit.

A kutatás többféle módon folytatható a jövőben. Először is mindenképpen érdemes a módszert más igealakokkal, illetve más szóosztályokkal is kipróbálni, 
hogy finomítani lehessen az elemzéseken, és az eredmények nagyobb fokú érvényességgel bírjanak. Másrészt hasznos lenne a kutatás használatalapúságát is fokozni: az egyes kollokációk, illetve konstrukciók metaforikus jellegét anyanyelvi nyelvhasználók körében tesztelni, hogy megállapíthassuk, valóban asszociálódnak-e egyes konstrukciós mintázatok bizonyos metaforikus jelentésekkel. Végül érdemes lenne más, akár specifikusabb korpuszokon is elvégezni az itt bemutatotthoz hasonló elemzéseket, sőt, akár a korpuszépítésbe is bevonni e tanulmány eredményeit, hogy azok alkalmazhatósága felmérhetővé váljon. A metafora nyelvtan- és korpuszvezérelt kutatása még csak kis léptékekben bontakozott ki, így hozadékai is részeredmények, ám remélhetően a jövőben egy átfogó kép áll majd össze ezekből a részletekből arról, milyen nyelvi folyamatok teszik lehetővé a metaforizációt.

\section{Köszönetnyilvánítás}

A tanulmány készítésekor a Magyar Tudományos Akadémia posztdoktori ösztöndíjában részesültem. A tanulmány megírását az OTKA K 100717 számú Kognitív nyelvészeti kutatás is támogatta. Hálásan köszönöm a tanulmány lelkiismeretes lektorainak, hogy észrevételeikkel, javaslataikkal segítették téziseim végső formába öntését.

\section{Hivatkozások}

Babarczy Anna - Simon Eszter 2012. A fogalmi metaforák és a szövegstatisztika szerepe a metaforák felismerésében. In Prószéky Gábor - Váradi Tamás (szerk.) Nyelvtechnológiai kutatások. (Általános Nyelvészeti Tanulmányok 24) Budapest: Akadémiai Kiadó. 223-242.

Baker, Paul 2016. The shapes of collocation. International Journal of Corpus Linguistics 21/2:139-164. doi:10.1075/ijcl.21.2.01bak.

Biber, Douglas 2010. Corpus-based and corpus-driven analysis of language variation and use. In Bernd Heine - Heiko Narrog (szerk.) The Oxford Handbook of Linguistic Analysis. Oxford: Oxford University Press. 159-192.

Brezina, Vaclav - Tony McEnery - Stephen Wattam 2015. Collocations in context. A new perspective on collocation networks. International Journal of Corpus Linguistics 20/2:139-173. doi:10.1075/ijcl.20.2.01bre.

Brunner, Annelen - Kathrin Steyer 2009. A model for corpus-driven exploration and presentation of multi-word expressions. In Jana Levická - Radovan Garabík (szerk.) NLP, Corpus Linguistics, Corpus Based Grammar Research. Bratislava: Tribun. 54-64.

Cheng, Winnie 2012. Exploring Corpus Linguistics. Language in Action. London, New York: Routledge.

Church, Kenneth Ward - Patrick Hanks 1990. Word association norms, mutual information, and lexicography. Computational Linguistics 16/1:22-29.

Croft, William 1993. The role of domains in the interpretation of metaphors and metonymies. Cognitive Linguistics 4/4:335-370.

doi:10.1515/cogl.1993.4.4.335.

Deignan, Alice 2005. Metaphor and Corpus Linguistics. (Converging Evidence in Language and Communication Research 6) Amsterdam: John Benjamins Publishing Company. 
Deignan, Alice 2006. The grammar of linguistic metaphors. In Anatol Stefanowitsch - Stefan Thomas Gries (szerk.) Corpus-based Approaches to Metaphor and Metonymy. Berlin, Boston: De Gruyter Mouton. doi:10.1515/9783110199895.106.

Deignan, Alice 2008. Corpus linguistic data and conceptual metaphor theory. In Mara Sophia Zanotto - Lynne Cameron - Marilda C. Cavalcanti (szerk.) Confronting Metaphor in Use. An Applied Linguistic Approach. (Pragmatics \& Beyond New Series 173) Amsterdam: John Benjamins Publishing Company. 149-162. doi:10.1075/pbns.173.10dei.

Hunston, Susan - Gill Francis 2000. Pattern Grammar. A corpus-driven approach to the lexical grammar of English. (Studies in Corpus Linguistics 4) Amsterdam: John Benjamins Publishing Company.

Huumo, Tuomas 2017. The grammar of temporal motion: A Cognitive Grammar account of motion metaphors of time. Cognitive Linguistics 28/1:1-43. doi:10.1515/cog-2016-0015.

Imrényi, András 2017. Form-meaning correspondences in multiple dimensions: The structure of Hungarian finite clauses. Cognitive Linguistics 28/2:287-319. doi:10.1515/cog-2016-0082.

Kövecses Zoltán 2009. Versengő metaforaelméletek? „Ez a sebész egy hentes”. Magyar Nyelv 105/3:271-280.

Ladányi Mária - Tolcsvai Nagy Gábor 2008. Funkcionális nyelvészet. In Tolcsvai Nagy Gábor - Ladányi Mária (szerk.) Tanulmányok a funkcionális nyelvészet köréből. (Általános Nyelvészeti Tanulmányok 22) Budapest: Akadémiai Kiadó. 17-58.

Lakoff, George 2006. Conceptual metaphor. The contemporary theory of metaphor. In Dirk Geeraerts (szerk.) Cognitive Linguistics: Basic Readings. Berlin, Boston: De Gruyter Mouton. 185-238. doi:10.1515/9783110199901.185.

Langacker, Ronald W. 1987. Foundations of Cognitive Grammar: Vol. 1. Theoretical Prerequisites. Stanford: Stanford University Press.

Langacker, Ronald W. 2008. Cognitive Grammar. A Basic Introduction. Oxford, New York: Oxford University Press.

Lederer, Jenny 2016. Finding source domain triggers. How corpus methodologies aid in the analysis of conceptual metaphor. International Journal of Corpus Linguistics 21/4:527-558. doi:10.1075/ijcl.21.4.04led.

Majoros Krisztián 2013. Metafora és kollokáció. In Váradi Tamás (szerk.) Alknyelvdok7. Doktoranduszok tanulmányai az alkalmazott nyelvészet köréból. Budapest: MTA Nyelvtudományi Intézet. 131-142.

Oravecz, Csaba - Tamás Váradi - Bálint Sass 2014. The Hungarian Gigaword Corpus. In Nicoletta Calzolari - Khalid Choukri - Thierry Declerck - Hrafn Loftsson - Bente Maegaard - Joseph Mariani - Asuncion Moreno - Jan Odijk - Stelios Piperidis (szerk.) Proceedings of the Ninth International Conference on Language Resources and Evaluation (LREC'14). Reykjavik: European Language Resources Association (ELRA). 1719-1723.

Reményi Andrea Ágnes 2010. Kollokációk korpuszalapú vizsgálata. Fordítástudomány 12:67-95. 
Rychlý, Pavel 2008. A lexicographer-friendly association score. In Petr Sojka - Aleš Horák (szerk.) RASLAN 2008: Recent Advances in Slavonic Natural Language Processing. Brno: Masaryk University. 6-9.

Semino, Elena 2006. A corpus-based study of metaphors for speech activity in British English. In Anatol Stefanowitsch - Stefan Thomas Gries (szerk.) Corpus-based Approaches to Metaphor and Metonymy. Berlin, Boston: De Gruyter Mouton. 36-62. doi:10.1515/9783110199895.36.

Simon Gábor 2016. A metaforikus jelentés nyelvtanvezérelt megközelítése. Magyar Nyelvör 140/2:178-199.

Steen, Gerard J. 2007. Finding Metaphor in Grammar and Usage. A Methodological Analysis of Theory and Research. Amsterdam: John Benjamins Publishing Company.

Steen, Gerard J. - Aletta G. Dorst - J. Berenike Herrmann - Anna Kaal - Tina Krennmayr - Trijntje Pasma 2010. A Method for Linguistic Metaphor Identification: From MIP to MIPVU. Amsterdam: John Benjamins Publishing Company.

Stefanowitsch, Anatol 2006a. Corpus-based approaches to metaphor and metonymy. In Anatol Stefanowitsch - Stefan Thomas Gries (szerk.) Corpusbased Approaches to Metaphor and Metonymy. Berlin, Boston: De Gruyter Mouton. 1-16. doi:10.1515/9783110199895.1.

Stefanowitsch, Anatol 2006b. Words and their metaphors: A corpus-based approach. In Anatol Stefanowitsch - Stefan Thomas Gries (szerk.) Corpus-based Approaches to Metaphor and Metonymy. Berlin, Boston: De Gruyter Mouton. 63-105. doi:10.1515/9783110199895.63.

Strugielska, Ariadna 2014. The place of metaphor in a devolved cognitive linguistics. metaphorik.de 25:103-127.

Sullivan, Karen 2009. Grammatical constructions in metaphoric language. In Barbara Lewandowska-Tomaszczyk - Katarzyna Dziwirek (szerk.) Studies in Cognitive Corpus Linguistics. (Łódź Studies in Language 18) Frankfurt am Main, New York: Peter Lang. 57-82.

Tognini-Bonelli, Elena 2001. Corpus linguistics at work. (Studies in Corpus Linguistics 6) Amsterdam: John Benjamins Publishing Company.

Tolcsvai Nagy Gábor 2013. Bevezetés a kognitív nyelvészetbe. Budapest: Osiris Kiadó.

\section{A szerzőről}

Simon Gábor az Eötvös Loránd Tudományegyetem Mai Magyar Nyelvi Tanszékének adjunktusa. Fő kutatási területe a kognitív poétika és a kognitív műfajelmélet, ugyanakkor a metaforikusság leírásával is foglalkozik, továbbá stíluselméleti kutatásokat is folytat. Két monográfia (Egy kognitív poétikai rímelmélet megalapozása, Bevezetés a kognitív lírapoétikába) szerzője.

Elérhetősége: simongabor@caesar.elte.hu 